\title{
Understanding the influence of the composition of the Ag-Pd catalysts on the selective formic acid decomposition and subsequent levulinic acid hydrogenation
}

Olga Sneka-Płatek, ${ }^{1, \dagger}$ Kamila Kaźmierczak, ${ }^{2, \dagger}$ Marcin Jędrzejczyk, ${ }^{1}$ Philippe Sautet, $, 2,4$ Nicolas Keller ${ }^{5}$, Carine Michel, ${ }^{2, *}$ Agnieszka M. Ruppert ${ }^{1, *}$

${ }^{1}$ Institute of General and Ecological Chemistry, Faculty of Chemistry, Lodz University of Technology, Żeromskiego 116, 90-924 Łódź, Poland

${ }^{2}$ University Lyon, ENS de Lyon, CNRS UMR 5182, Université Claude Bernard Lyon 1, Laboratoire de Chimie, 46 Allee d'Italie, 69342, Lyon, France

${ }^{3}$ Department of Chemical and Biomolecular Engineering, University of California, Los Angeles, Los Angeles, California 90095, United States

${ }^{4}$ Department of Chemistry and Biochemistry, University of California, Los Angeles, Los Angeles, California 90095, United States

${ }^{5}$ Institut de Chimie et Procédés pour l'Energie, l'Environnement et la Santé, ICPEES, CNRS, University of Strasbourg, 25 rue Becquerel, 67087 Strasbourg, France

$\dagger$ - The authors contributed equally

* - Corresponding authors: agnieszka.ruppert@p.lodz.pl and carine.michel@ens-lyon.fr

\begin{abstract}
Formic acid is obtained in equimolar amount with levulinic acid during the hydrolysis of cellulose and thus can be used as a sustainable hydrogen source in the direct levulinic acid hydrogenation towards gamma-valerolactone (biofuel additive). Ag-Pd catalysts prepared by various methods and containing different $\mathrm{Ag}: \mathrm{Pd}$ ratio were investigated in this context. By combining activity tests, characterization of the main physicochemical properties of the catalysts and DFT study of formic acid decomposition, the key factors responsible for the activity of Ag-Pd catalysts in both the formic acid decomposition and the subsequent hydrogenation of levulinic acid were specified. Pd is shown to be active, but prone to poisoning by $\mathrm{CO}$, while the $\mathrm{CO}$ poisoning remains limited on diluted Ag-Pd alloy with strong
\end{abstract}


intermetallic interaction, where its adsorption is very weak thanks to the isolation of Pd atoms. Therefore, the catalyst containing $4 \% \mathrm{Ag}-1 \% \mathrm{Pd} / \mathrm{AlOOH}$ showed the highest selectivity in formic acid decomposition as well as the highest activity in levulinic acid hydrogenation (34\% conversion in $5 \mathrm{~h}$ at $190^{\circ} \mathrm{C}$ ).

Keywords: formic acid, Ag-Pd catalysts, DFT study, hydrogen transfer, levulinic acid, biomass

\section{Introduction}

Formic acid (FA), besides being a suitable hydrogen storage material for fuel cell applications, ${ }^{1,2,3,4,5}$ is a sustainable hydrogen source for hydrogenation reactions. ${ }^{6}$ Although a lot of work has been recently done in the field of fuel cells, performing the selective decomposition of FA for hydrogen transfer reactions in the presence of different solvents and in high temperature reaction conditions still remains a challenge. ${ }^{7}$ Active catalyst capable of selectively decomposing FA via dehydrogenation path into $\mathrm{H}_{2}$ and $\mathrm{CO}_{2}$ is required. By contrast, the FA dehydration reaction into $\mathrm{CO}$ and $\mathrm{H}_{2} \mathrm{O}$ is undesirable due to strong $\mathrm{CO}$ adsorption on the metal surface, which might be a reason of the poisoning of the metallic active sites of heterogeneous catalysts. ${ }^{8,9}$ This is even more critical in the case of hydrogen transfer reaction where the hydrogen is produced in situ and directly used. The latter is a very appealing approach to valorize cellulosic biomass feedstock in a Green Chemistry based methodology. For instance, levulinic acid (LA) is formed in equimolar amount with FA during the hydrolysis of cellulose. ${ }^{10} \mathrm{LA}$ is an important platform molecule derived from biomass, and it can be further hydrogenated to gamma-valerolactone (GVL), which is considered as a potential biofuel additive. ${ }^{11,12}$

The conversion of LA to GVL is mainly addressed using an external source of hydrogen (pressure of $\mathrm{H}_{2}$ above 30 bar) and supported mono-metallic catalysts, i.e. $\mathrm{Ru}, \mathrm{Ni}, \mathrm{Cu} .{ }^{13,14}$ One of the ways for boosting the catalytic efficiency is based on the modification of the properties of the catalysts via the addition of a second metal. ${ }^{15,16}$ This can significantly change the electronic properties of the active phase as well as the dispersion and the size of the metal particles on the support due to mutual interaction of the metals. ${ }^{17}$ While $\mathrm{Au} / \mathrm{TiO}{ }_{2}$ and $\mathrm{Pd} / \mathrm{TiO}_{2}$ 
were almost not active in LA hydrogenation (4\% and 3\% of conversion, respectively), Au$\mathrm{Pd} / \mathrm{TiO}_{2}$ allowed to reach $90 \%$ of LA conversion and obtain GVL with $98 \%$ of selectivity as shown by Luo et al. ${ }^{18}$

While several catalysts are performing extremely well in the levulinic acid hydrogenation using an external source of hydrogen $\left(\mathrm{H}_{2}\right.$ pressure), not as much showed a reasonable activity when formic acid is used as an internal $\mathrm{H}_{2}$ source. ${ }^{19}$ The challenge is to find a catalytic system able to promote simultaneously the FA selective decomposition and the LA hydrogenation reactions. ${ }^{20}$ The chance for this is again in bimetallic catalysts, which were shown to perform better than their monometallic counterparts. ${ }^{21,22,23}$ Besides, during the investigations, FA decomposition was identified as a crucial step for further ongoing of the combined reaction. ${ }^{20,23}$

Monometallic heterogeneous catalysts are mostly not showing satisfactory properties in FA decomposition, therefore there is intensive research for tuning their properties and optimizing the catalytic performances. A great attention has been put on the Ag-Pd systems due to their highly promising catalytic performances. So far, numerous preparation methods have been applied to synthesize Ag-Pd catalysts, which resulted in the synthesis of materials possessing different compositions, size and morphology of nanoparticles. ${ }^{24,25}$ However, the key factors controlling the catalytic performance are still debated. Neither the optimal ratio nor the most favorable morphology is established for getting active and selective catalysts in FA decomposition in a broad reaction condition range.

Ag-Pd catalysts prepared by different methods and possessing different composition are reported as optimal for the FA dehydrogenation. Tedsree et al. communicated the advantageous usage of $\mathrm{Ag} @ \mathrm{Pd}$ core@shell catalysts in the hydrogen production from FA at room temperature in comparison to other core@shell Pd based materials.Erreur ! Signet non défini. They evidenced that $\mathrm{Ag} @ \mathrm{Pd}$ core@shell structured nanocatalysts were more active and selective to $\mathrm{H}_{2}$ than bare $\mathrm{Pd}$, for a $\mathrm{Ag}: \mathrm{Pd}$ molar ratio of 1:1. The improved catalytic properties were attributed to the charge transfer from the Ag metal core to the Pd shell, which lead to differences in term of work function and consequently strengthen the adsorption of formate.

Following this, Hattori et al. synthesized AgPd@Pd/TiO 2 catalyst, ${ }^{26}$ which allowed to enhance the hydrogen production at ambient temperature by 2-4 folds in comparison to that of the previous investigation of Tedsree et al. Such a good activity was explained by the lowering of the energy barrier caused by the strong electron-donating effects of $\mathrm{TiO}_{2}$ to $\mathrm{Pd}$ shells. The 
optimum Ag:Pd composition was however moved towards a higher content in $\mathrm{Ag}$, i.e. at $\mathrm{Ag}_{82} \mathrm{Pd}_{18} @ \mathrm{Pd}$.

These observations are in line with the work of Huang et al., ${ }^{27}$ but a different optimal Ag:Pd molar ratio has been proposed in the case of nitrogen-modified graphene oxide supported bimetallic catalysts. The catalyst activity increased with the Ag:Pd ratio up to $6: 1$, and then decreased for higher ratios, which was related with $\mathrm{AgPd}$ alloy formation and existence of AgPd strong synergetic effects.

On the other hand, Liu et al. ${ }^{28}$ showed that $\mathrm{Ag}: \mathrm{Pd}$ ratio of 1:3 was optimal for getting a high activity in FA decomposition on bimetallic Ag-Pd agglomerated catalysts.

In short, despite the significant findings showing the high activity in FA decomposition of the Ag-Pd catalysts, there are still many gaps in the current state of knowledge. The optimal metal ratio of $\mathrm{Ag}-\mathrm{Pd}$ is still under debate as it strongly depends on the preparation method, support nature and on the reaction conditions. The reason of the very good catalytic performances achieved on Ag-Pd catalysts are still not fully clarified.

DFT modeling was performed to better understand the catalytic activity of monometallic and bimetallic heterogeneous catalysts in FA $(\mathrm{HCOOH})$ decomposition. Herron et al. ${ }^{29}$ showed that it proceeds preferentially on $\mathrm{Pd}$, whereas $\mathrm{Ag}$ is predicted to be inert in the reaction. Without solvation, the formate (via $\mathrm{HCOO}$ ) and carboxyl (via $\mathrm{COOH}$ ) pathways are concurring FA decomposition routes on the Pd surface. Later, Wang et al. ${ }^{30}$ showed that the preferred reaction pathway depends on the $\mathrm{pH}$, conditioned by the addition of reaction promoter. Bimetallic surfaces can be considered as core@shell or alloy type structures. ${ }^{31}, 32$ Cho et al. ${ }^{33}$ investigated the effect of the thickness of Pd layer covering the Ag core, finding out that the dehydrogenation reaction is preferred over dehydration for thinner Pd shell. Alloy type Pd-Cu systems were studied by Zhang et al. ${ }^{34}$ showing that the addition of $\mathrm{Cu}$ improves the catalysts activity, and may influence the reaction selectivity towards $\mathrm{H}_{2}$ and $\mathrm{CO}_{2}$ vs $\mathrm{H}_{2} \mathrm{O}$ and $\mathrm{CO}$.

To the best of our knowledge, the studies devoted to the FA decomposition with Ag-Pd catalysts are only/mostly performed at low temperatures optimized for fuel cell applications. There is little information concerning the FA decomposition in the one-pot reaction for subsequent hydrogenation process. Moreover, the implementation of bimetallic Ag-Pd catalysts for two different and consecutive reactions (FA decomposition and LA hydrogenation) was not described before. Therefore, our work aims at optimizing the Ag-Pd 
catalysts for the hydrogen transfer reaction in the high temperature process. In order to demonstrate the catalytic performance in the tandem, one-pot process, we studied both the FA decomposition and the direct LA hydrogenation reactions. In addition, DFT computations were performed to investigate the FA decomposition by bimetallic catalysts. The main goal of this study is therefore to understand the factors responsible for the activity and selectivity of the Ag-Pd catalysts in liquid phase reaction conditions. Additionally, our aim is to determine the optimal ratio of $\mathrm{Ag}-\mathrm{Pd}$ and preparation methods in bimetallic catalyst to reach high activity and selectivity in FA decomposition towards hydrogen and additionally subsequent hydrogenation in the one-pot tandem process.

\section{Experimental}

\subsection{Catalysts synthesis}

High surface area hydrated aluminum oxide Brockmann II, neutral (AlOOH, boehmite; 123 $\mathrm{m}^{2} / \mathrm{g}$ ) was used as received from Roanal (Budapest, Hungary) in the synthesis of all the catalysts.

\section{Preparation of the monometallic catalysts}

The Ag monometallic catalyst supported on $\mathrm{AlOOH}$ was prepared with a $5 \mathrm{wt} \%$ metal content using solid silver nitrate (POCH S.A., pure). The support was impregnated by the 50 $\mathrm{mL}$ aqueous solution of $\mathrm{AgNO}_{3}$ and aged for $24 \mathrm{~h}$ at room temperature. After evaporation of water, the catalyst was dried at $120^{\circ} \mathrm{C}$ for $2 \mathrm{~h}$ and reduced in hydrogen flow at $400^{\circ} \mathrm{C}$ for $1 \mathrm{~h}$ with a heating rate of $10^{\circ} \mathrm{C} / \mathrm{min}$. This sample is labeled as $5 \% \mathrm{Ag} / \mathrm{AlOOH}$.

The Pd monometallic catalyst supported on $\mathrm{AlOOH}$ was prepared with a $5 \mathrm{wt} \%$ metal content using $\mathrm{PdCl}_{2}$ (POCH S.A., pure) salt as a palladium precursor, which was dissolved in $0.5 \mathrm{M} \mathrm{HCl}$ aqueous solution. The concentration of $\mathrm{Pd}$ in obtained solution was $1.18 \mathrm{~g} / \mathrm{L}$. The support was impregnated by the aqueous solution of $\mathrm{PdCl}_{2}$, diluted with $50 \mathrm{~mL}$ of water, and aged for $24 \mathrm{~h}$ at room temperature. After evaporation of water, the catalyst was dried at $120^{\circ} \mathrm{C}$ for $2 \mathrm{~h}$ and reduced in hydrogen flow at $400^{\circ} \mathrm{C}$ for $1 \mathrm{~h}$ with a heating rate of $10^{\circ} \mathrm{C} / \mathrm{min}$. This sample is labeled as $5 \% \mathrm{Pd} / \mathrm{AlOOH}$.

\section{Preparation of the bimetallic catalysts}


Using the same catalysts precursors as in monometallic catalysts preparation, the Ag-Pd bimetallic catalysts supported on $\mathrm{AlOOH}$, were prepared with a different total metal content of: $5 \mathrm{wt} \%$ with $\mathrm{Ag}: \mathrm{Pd}$ wt. ratio of 4:1 and 4.5:0.5; $10 \mathrm{wt} \%$ with $\mathrm{Ag}: \mathrm{Pd}$ wt. ratio of 9:1; and 15 wt $\%$ with Ag:Pd wt. ratio of 14:1. Due to the very similar molecular mass of Ag and Pd, the wt. ratio is equivalent to molar ratio between the elements. The Ag-Pd bimetallic catalysts were prepared by following different impregnation procedures.

\section{The co-impregnation method (CIMP)}

The Ag-Pd bimetallic catalysts were prepared by the co-impregnation method (CIMP). The mass and solutions volume of the metal salts and the support amount were chosen to maintain given Ag:Pd wt.\% ratio using silver nitrate and palladium chloride as metal precursors. Catalysts were dried at $120^{\circ} \mathrm{C}$ for $2 \mathrm{~h}$, then reduced in hydrogen flow at $400^{\circ} \mathrm{C}$ for $1 \mathrm{~h}$ with heating rate of $10{ }^{\circ} \mathrm{C} / \mathrm{min}$. These samples were labeled as $4 \% \mathrm{Ag}-1 \% \mathrm{Pd} / \mathrm{AlOOH}_{(\mathrm{CIMP})}, 4.5 \%$ $\mathrm{Ag}-0.5 \% \mathrm{Pd} / \mathrm{AlOOH}_{(\mathrm{CIMP})}, 9 \% \mathrm{Ag}-1 \% \mathrm{Pd} / \mathrm{AlOOH}_{(\mathrm{CIMP})}$ and $14 \% \mathrm{Ag}-1 \% \mathrm{Pd} / \mathrm{AlOOH}_{(\mathrm{CIMP})}$.

\section{The subsequent impregnation method (SIMP)}

The AlOOH support was impregnated first with $50 \mathrm{~mL}$ of the aqueous silver nitrate solution and aged for $24 \mathrm{~h}$ at room temperature. The catalyst was further dried at $120^{\circ} \mathrm{C}$ for $2 \mathrm{~h}$ after complete evaporation of the solvent. The resulting powder was then impregnated with the palladium chloride solution. The sample was again aged for $24 \mathrm{~h}$ at room temperature, and after solvent evaporation, dried for $2 \mathrm{~h}$ at $120^{\circ} \mathrm{C}$. At the end, the catalyst was reduced in hydrogen flow at $400^{\circ} \mathrm{C}$ for $1 \mathrm{~h}$ with heating rate of $10^{\circ} \mathrm{C} / \mathrm{min}$. This sample was labeled as $4 \% \mathrm{Ag}-1 \% \mathrm{Pd} / \mathrm{AlOOH}_{(\mathrm{SIMP})}$.

\section{The co-impregnation method with chemical reduction (CIMP-CR)}

The $25 \mathrm{~mL}$ of aqueous silver nitrate solution was first mixed with water solution of poly(vinyl alcohol) polymer (PVA) (Mw = $9000-10$ 000, 80\% hydrolyzed, Sigma Aldrich), maintaining the mass ratio $\mathrm{m}_{\mathrm{AgNO} 3}: \mathrm{m}_{\mathrm{PVA}}=1: 1$. After 10 minutes of mixing $\mathrm{NaBH}_{4}$ was added, in 5 -fold excess $\left(\mathrm{n}_{\mathrm{Ag}}: \mathrm{n}_{\mathrm{NaBH} 4}=1: 5\right)$. Then the aqueous solution of palladium chloride and PVA, with the same mass ratio, was added to the mixture and further reduced with use of $\mathrm{NaBH}_{4}$ in 5fold excess $\left(\mathrm{n}_{\mathrm{Pd}}: \mathrm{n}_{\mathrm{NaBH} 4}=1: 5\right)$. In the final step, $\mathrm{AlOOH}$ was added and the catalyst was stirred until solution decolorization (until impregnation of PVA stabilized metals on a support). The catalyst was filtered off with a water pump and washed intensively with distilled water. After drying at $90^{\circ} \mathrm{C}$ for $2 \mathrm{~h}$, the catalyst was used in reaction without further treatment. This sample 
was labeled as $4 \% \mathrm{Ag}-1 \% \mathrm{Pd} / \mathrm{AlOOH}_{(\mathrm{CIMP}-\mathrm{CR})}$. Whole synthesis was conducted under inert atmosphere, assured by Ar flow.

\section{The subsequent impregnation method with chemical reduction (SIMP-CR)}

The $25 \mathrm{~mL}$ aqueous silver nitrate solution was first mixed with water solution of PVA (Mw $=$ $9000-10000,80 \%$ hydrolyzed, Sigma Aldrich), maintaining the mass ratio $\mathrm{m}_{\mathrm{AgNO} 3}: \mathrm{m}_{\mathrm{PVA}}=$ 1:1. After 10 minutes of mixing $\mathrm{NaBH}_{4}$ was added, in 5-fold excess $\left(\mathrm{n}_{\mathrm{Ag}}: \mathrm{n}_{\mathrm{NaBH}}=1: 5\right)$. Then, $\mathrm{AlOOH}$ was added and the resulting mixture was mixed until solution decolorization. After, the aqueous solution of palladium chloride and PVA, which was prepared in the same mass ratio, was added to the solution and further reduced again with use of $\mathrm{NaBH}_{4}$ in 5-fold excess $\left(\mathrm{n}_{\mathrm{Pd}}: \mathrm{n}_{\mathrm{NaBH} 4}=1: 5\right)$. At the end, the catalyst was stirred until solution decolorization and filtered off with a water pump and intensively washed with distilled water. After drying at $90^{\circ} \mathrm{C}$ for $2 \mathrm{~h}$, catalyst was used in reaction without further treatment. This sample was labeled as $4 \% \mathrm{Ag}-1 \% \mathrm{Pd} / \mathrm{AlOOH}_{(\mathrm{SIMP}-\mathrm{CR})}$. Whole synthesis was conducted under inert atmosphere, assured by Ar flow.

Whatever the catalyst prepared and the wet impregnation method used, known to allow a precise control of the catalyst metal content, the proportion of the metal content in the different catalysts is the feed ratio.

\subsection{Catalysts characterization}

The surface area and porosimetry measurements were carried out on a sorptometer Micromeritics ASAP 2020 V3.05 G (Surface Area and Porosity Analyzer). Samples were firstly outgassed at $350^{\circ} \mathrm{C}$ during $4 \mathrm{~h}$. The BET specific surface area was calculated from the $\mathrm{N}_{2}$ adsorption isotherm.

Temperature-programmed reduction (TPR) was used for examining the reducibility of catalysts. The measurements were performed on AMI1 system manufactured by Altamira Instruments, USA, equipped with a thermal conductivity detector. The samples after drying step were subjected to the measurements. For all samples, the TPR profiles were recorded from $30^{\circ} \mathrm{C}$ up to $500^{\circ} \mathrm{C}$, with a heating rate of $10^{\circ} \mathrm{C} / \mathrm{min}$.

X-ray diffraction (XRD) measurements were carried out on a D8 Advance Bruker

diffractometer, in a $\theta / 2 \theta$ mode and using the $K_{\alpha 1}$ radiation of $\mathrm{Cu}$ at $1.5406 \AA$. The measurements were performed in $5-90^{\circ} 2 \theta$ range with goniometer rotation speed at $0.05 \% \mathrm{~min}$. 
Secondary ion mass spectra were recorded with a Time-of-Flight Secondary Ion Mass Spectrometer (ToF-SIMS IV) manufactured by ION-TOF GmbH, Germany, equipped with $25 \mathrm{kV}$ pulsed $\mathrm{Bi}^{+}$primary ion gun in the static mode. The samples were fixed to the sample holder by double sided adhesive tape. The analyzed area of the sample surface was $500 \mu \mathrm{m} \times$ $500 \mu \mathrm{m}$. During analysis, a pulsed low-energy electron flood gun was used for charge neutralization. Every single sample was analyzed three times.

X-ray photoelectron spectroscopy (XPS) characterization was performed on a respectively ThermoVGMultilabESCA3000 spectrometer $\left(\mathrm{A} 1 \mathrm{~K}_{\alpha}\right.$ anode at $\mathrm{h} \lambda=1486.6$ $\mathrm{eV}$ ). The energy shift due to electrostatic charging was subtracted using the contamination $\mathrm{sp}^{2}$ carbon $\mathrm{C} 1 \mathrm{~s}$ band at $284.6 \mathrm{eV}$. Contributions with Doniach-Sunjic shape ${ }^{35}$ and a' S-shaped' Shirley type background ${ }^{36}$ were used. Surface atomic ratios were derived using the appropriate experimental sensitivity factors ${ }^{37}$.

\subsection{Catalytic tests}

\section{Formic acid (FA) decomposition}

In a typical formic acid (FA; Chempur, 85\%) decomposition experiment, $0.4 \mathrm{~mL}$ of FA aqueous solution $(0.0088 \mathrm{~mol}), 0.3 \mathrm{~g}$ of reduced catalyst and $30 \mathrm{~mL}$ of water were combined in a stainless-steel autoclave (Berghof, Germany), equipped with teflon insert with a maximum reaction volume of $45 \mathrm{~mL}$. The reactor bed was flushed with hydrogen for 30 seconds and argon for 15 seconds. Then, the reactor was heated at $190^{\circ} \mathrm{C}$ and hold for the respective reaction time.

\section{Levulinic acid (LA) hydrogenation}

In a typical levulinic acid (LA; Aldrich Chemistry, 98\%) hydrogenation experiment, $1 \mathrm{~g}$ of LA $(0.0086 \mathrm{~mol}), 0.3 \mathrm{~g}$ of catalyst and $30 \mathrm{~mL}$ of water were combined in a stainless-steel autoclave (Berghof, Germany), equipped with teflon insert with a maximum reaction volume of $45 \mathrm{~mL}$. The reactor was pressurized with $\mathrm{H}_{2}$ to 10 bar and temperature was maintained at $190^{\circ} \mathrm{C}$ for $2 \mathrm{~h}$. The chosen pressure is equal to the pressure cause by the FA decomposition during the reaction.

Formic acid (FA) decomposition with simultaneous levulinic acid (LA) hydrogenation (FALA) 
In a typical LA hydrogenation experiment, $1 \mathrm{~g}$ of LA $(0.0086 \mathrm{~mol})$ and $0.4 \mathrm{~mL}$ of FA aqueous solution $(0.0088 \mathrm{~mol})$ corresponding to a LA/FA equimolar ratio were combined with $0.6 \mathrm{~g}$ of a catalyst in $30 \mathrm{~mL}$ of water were combined in a stainless-steel autoclave (Berghof), equipped with teflon insert with a maximum reaction volume of $45 \mathrm{~mL}$. The temperature was maintained at $190^{\circ} \mathrm{C}$ for $5 \mathrm{~h}$.

\section{Reaction product analysis}

Gaseous products which were collected at the end of the reaction in the trap were analyzed by gas chromatograph (VEB Chromatrom, Berlin) equipped with the TCD detector. Liquid products were analyzed by high-performance liquid chromatograph Agilent Technologies 1260 Infinity manufactured by Perlan Technologies equipped with refractive index detector and Rezex ROA column. The sulphuric acid $\left(\mathrm{H}_{2} \mathrm{SO}_{4}\right)$ with molar concentration of 0.0025 $\mathrm{mol} / \mathrm{L}$ was used as an eluent.

\subsection{Computational details}

Periodic Density Functional Theory (DFT) calculations were carried out with the Vienna Ab Initio Simulation Package (VASP). ${ }^{38}$ The exchange-correlation energy and potential were calculated with the generalized gradient approximation (GGA) using the PBE functional ${ }^{39}$ and including the $\mathrm{dDsC}$ dispersion correction, ${ }^{40,41}$ a combination recently benchmarked against experimental adsorption energies. ${ }^{42}$ A tight convergence of the plane-wave expansion was obtained with a cut-off of $400 \mathrm{eV}$. The electron-ion interactions were described by the projector augmented wave method (PAW). ${ }^{43,44}$ The self-consistent field convergence criterion was set at $10^{-6} \mathrm{eV}$ and the tag controlling the numerical accuracy to Normal.

Close-packed (111) monometallic (Ag and Pd) and bimetallic (Ag-Pd) surfaces were modelled by a four-layer slab, separated by at least $10 \AA$ of vacuum and using $\mathrm{p}(3 \times 3)$ supercell. A Monkhorst-Pack mesh of $3 \times 3 \times 1$ K-points for all surfaces were used for the 2D Brillouin zone integration ${ }^{45}$. The two bottom layers were kept fixed at the optimized bulk-truncated positions (with an optimized metal-metal distance of $2.92 \AA$ and $2.78 \AA$ for $\mathrm{Ag}$ and $\mathrm{Pd}$ respectively, which corresponds to an overestimation of $1 \%$ versus experimental values). The coordinates of two uppermost layers and of the adsorbates were allowed to relax until forces were less than $0.015 \mathrm{eV} / \AA$. Adsorption and reaction processes were realized on the upper surface of the slab. Two bimetallic (111) surfaces were used to model the Ag-Pd system. To represent the core@shell type structures, $\mathrm{Ag} @ \mathrm{Pd}$ is composed of one top Pd layer and three $\mathrm{Ag}$ layers underneath. To represent the sites where $\mathrm{Pd}$ is diluted in $\mathrm{Ag}, 1 \mathrm{Pd}-\mathrm{Ag}$ exposes one 
isolated Pd atom in the topmost layer of a Ag slab. (For the slab structures see Figure S1 in Supporting Information.) Only composed of Ag, the bottom layers of the bimetallic structures are fixed at the optimal bulk $\mathrm{Ag}$ interatomic distance.

The Gibbs energy of adsorption $\left(\Delta \mathrm{G}_{\mathrm{ads}}\right)$ of a molecule from the gas phase is considered as:

$$
\Delta \mathrm{G}_{\mathrm{ads}}=\mathrm{G}_{\mathrm{ads} / \mathrm{slab}}-\left(\mathrm{G}_{\mathrm{slab}}+\mathrm{G}_{\mathrm{mol}}\right)
$$

with $\mathrm{G}_{\text {slab }}$ the Gibbs energy of the pristine slab, $\mathrm{G}_{\mathrm{mol}}$ the Gibbs energy of the molecule and $\mathrm{G}_{\mathrm{ads} / \mathrm{slab}}$ the Gibbs energy of the molecule adsorbed on the surface. A negative Gibbs energy of adsorption corresponds to stabilizing interactions.

The $\mathrm{G}_{\mathrm{mol}}$ is calculated within the harmonic approximation, the rigid rotator and the perfect gas model as follow:

$$
\mathrm{G}_{\mathrm{mol}}=\mathrm{E}_{\mathrm{elec}}+\mathrm{ZPE}+\mathrm{nk}_{\mathrm{B}} \mathrm{T}-\left(\mathrm{S}_{\text {trans }}+\mathrm{S}_{\mathrm{rot}}+\mathrm{S}_{\mathrm{vib}}\right) \cdot \mathrm{T}
$$

with:

$E_{\text {elec }}-$ electronic energy

ZPE - zero-point energy

$\mathrm{n}$ - factor, $\mathrm{n}=4$ for non-linear molecules, $\mathrm{n}=3.5$ for linear molecules

$\mathrm{k}_{\mathrm{B}}$ - Boltzmann constant

$\mathrm{T}$ - temperature (equal to $463.15 \mathrm{~K}=190^{\circ} \mathrm{C}$ )

$\mathrm{S}_{\text {trans, }}, \mathrm{S}_{\mathrm{rot}}, \mathrm{S}_{\mathrm{vib}}$ - translational, rotational and vibrational entropy, respectively

To better approximate the reaction conditions, the entropy of species in the condensed liquid phase (FA and water) is evaluated as half of the one computed in gas phase. ${ }^{46}$ As well, an artificial energy correction of $-0.43 \mathrm{eV}$ was applied to the energy of $\mathrm{CO}$ in gas phase to correct the gas phase Gibbs energy of the formic acid dehydration reaction. ${ }^{47}$

Upon adsorption, the adsorbate is assumed to completely lose its translational and rotational degrees of freedom, and thus $\mathrm{G}_{\mathrm{ads} / \mathrm{slab}}$ and $\mathrm{G}_{\text {slab }}$ are considered as:

$$
\begin{gathered}
\mathrm{G}_{\text {slab }}=\mathrm{E}_{\text {elec }}+\mathrm{ZPE}-\mathrm{S}_{\mathrm{vib}} \cdot \mathrm{T} \\
\mathrm{G}_{\mathrm{ads} / \mathrm{slab}}=\mathrm{E}_{\text {elec }}+\mathrm{ZPE}-\mathrm{S}_{\mathrm{vib}} \cdot \mathrm{T}
\end{gathered}
$$

Reactions paths have been studied by combining nudge elastic band procedures (NEB), ${ }^{48,49}$ together with our local reaction path generator, OpenPath. ${ }^{50}$ Transitions states have been optimized using the dimer algorithm, ${ }^{51}$ and confirmed by the presence of a single imaginary frequency, which normal mode corresponds to a motion along the reaction coordinate. 
To determine the effective reaction energy barrier, the energy span model formalized by Kozuch and Shaik is applied. ${ }^{52,53}$ The energy span $\left(\delta \mathrm{G}_{\mathrm{span}}\right)$ is defined as the difference in Gibbs free energy between the TOF-determining intermediate (TDI) and TOF-determining transition state (TDTS):

$$
\delta G_{\text {span }}=\left\{\begin{array}{cl}
G_{T D T S}-G_{T D I} & \text { when TDTS appears after TDI } \\
G_{T D T S}-G_{T D I}+\Delta G_{r} & \text { when TDTS appears before TDI }
\end{array}\right.
$$

TDTS and TDI maximize this Gibbs Energy span and thus control the reaction kinetics.

\section{Results and discussion}

\subsection{Catalytic activity in formic acid decomposition}

The activity of monometallic and bimetallic catalysts in formic acid decomposition is presented in Table 1. Let us start with the monometallic catalysts. The monometallic palladium supported on boehmite showed a higher conversion of formic acid (79\%) than the silver catalyst $(23 \%)$, whereas the thermal decomposition of FA lead to $5 \%$ conversion and the activity of the bare support was $11 \%$.

The highest selectivity towards hydrogen was observed for monometallic palladium, in that case only traces of $\mathrm{CO}$ were observed. For the monometallic Ag the situation was different and larger amount of $\mathrm{CO}$ was formed.

Table 1. FA decomposition over mono- and bimetallic catalysts and support.

\begin{tabular}{|cccccc|}
\hline Catalyst & $\begin{array}{c}\text { FA } \\
\text { conversion } \\
(\%)\end{array}$ & $\mathbf{H}_{\mathbf{2}}$ & $\mathbf{C O}$ & $\mathbf{C H}_{\mathbf{4}}$ & $\mathbf{C O}_{\mathbf{2}}$ \\
\hline- & 5 & 37 & 29 & 0 & 34 \\
$\mathrm{AlOOH}$ & 11 & 25 & 16 & 0 & 59 \\
$5 \% \mathrm{Pd} / \mathrm{AlOOH}$ & 79 & 55 & 2 & 0 & 43 \\
$5 \% \mathrm{Ag} / \mathrm{AlOOH}$ & 23 & 44 & 10 & 0 & 46 \\
$4 \% \mathrm{Ag}-1 \% \mathrm{Pd} / \mathrm{AllOH}_{(\mathrm{CIMP})}$ & 100 & 49 & 11 & 2 & 38 \\
$4 \% \mathrm{Ag}-1 \% \mathrm{Pd} / \mathrm{AlOOH}_{(\mathrm{SIMP})}$ & 100 & 55 & 13 & 0 & 32 \\
$4 \% \mathrm{Ag}-1 \% \mathrm{Pd} / \mathrm{AlOOH}_{(\mathrm{CIMP}-\mathrm{CR})}$ & 100 & 40 & 3 & 0 & 57
\end{tabular}


Experimental conditions: $190^{\circ} \mathrm{C} ; 2 \mathrm{~h} ; 0.4 \mathrm{~mL}$ of FA; $0.3 \mathrm{~g}$ of catalyst.

Table 2. FA decomposition over mono- and bimetallic catalysts and bare support for shortened reaction time.*

\begin{tabular}{|c|c|c|c|c|c|}
\hline \multirow{2}{*}{ Catalyst } & \multirow{2}{*}{$\begin{array}{c}\text { FA } \\
\text { conversion } \\
(\%)\end{array}$} & \multicolumn{4}{|c|}{ Gaseous products (\%) } \\
\hline & & $\mathbf{H}_{2}$ & $\mathrm{CO}$ & $\mathrm{CH}_{4}$ & $\mathrm{CO}_{2}$ \\
\hline $4 \% \mathrm{Ag}-1 \% \mathrm{Pd} / \mathrm{AlOOH}_{(\mathrm{CIMP})}$ & 65 & 52 & 0 & 1 & 47 \\
\hline 4\%Ag-1\%Pd/AlOOH (SIMP) & 28 & 48 & 18 & 0 & 34 \\
\hline $4 \% \mathrm{Ag}-1 \% \mathrm{Pd} / \mathrm{AlOOH}\left(\mathrm{CIMP}_{-\mathrm{CR})}\right.$ & 32 & 53 & 5 & 0 & 42 \\
\hline $4 \% \mathrm{Ag}-1 \% \mathrm{Pd} / \mathrm{AlOOH}\left(\mathrm{SIMP}_{\mathrm{CR}}\right)$ & 30 & 55 & 0 & 0 & 45 \\
\hline $\begin{array}{l}\text { Experimental condi } \\
{ }^{*} \text { The reaction was conducte }\end{array}$ & $\begin{array}{l}\text { Is: } 190^{\circ} \mathrm{C} ; 0.4 \\
\text { ll the tempera } \\
\text { immediately }\end{array}$ & $\begin{array}{l}\text { of } \\
\text { e re }\end{array}$ & $\begin{array}{l}.3 \mathrm{~g} \\
190\end{array}$ & $\begin{array}{l}\text { alyst. } \\
\text { I was s }\end{array}$ & \\
\hline
\end{tabular}

Overall for all bimetallic catalysts an increased FA conversion, in comparison to the monometallic counterparts, was noticed. Indeed, when performing the reaction for $2 \mathrm{~h}$, a $100 \%$ conversion was systematically reached whatever the preparation method (Table 1). To limit this conversion and allow a comparison, reactions were performed for shortened reaction time (Table 2). The highest conversion was observed for the material prepared by co-impregnation (CIMP) method. Also, the selectivity towards hydrogen was very high in this case, since no CO was identified. The catalysts prepared by the other methods (SIMP, and methods with chemical reduction: SIMP-CR and CIMP-CR) showed a bit lower activity in the reaction. These catalysts differ as well in the selectivity. The ones prepared by the chemical reduction allowed forming more hydrogen, whereas for the catalyst prepared by the SIMP method the highest amount of $\mathrm{CO}$ was observed.

The next part of the investigations was devoted to the influence of the catalyst's composition, particularly the Ag:Pd ratio, on their catalytic performance. Considering that $\mathrm{Ag}$ alone has limited activity in FA decomposition, our approach was to check the effect of the palladium dilution by silver NPs and the influence of the contact enhancement between these two metals. Therefore, the following Ag:Pd ratios of 4:1, 9:1 and 14:1 were investigated (Table 3).

The highest FA conversion (92\%) was observed in the case of $9 \% \mathrm{Ag}-1 \% \mathrm{Pd} / \mathrm{AlOOH}$ catalyst. The increase of the conversion was however associated with a low selectivity, as $23 \%$ of CO 
was obtained. For both lower and higher Ag content the conversion of FA was similar (65 and $61 \%$ respectively). The highest selectivity towards hydrogen was observed for $4 \% \mathrm{Ag}$ $1 \% \mathrm{Pd} / \mathrm{AlOOH}$ catalyst, whereas higher $\mathrm{CO}$ formation was noticed for $\mathrm{Ag} / \mathrm{Pd}$ ratio higher than 4:1. Comparing two catalysts with the same molar Ag:Pd ratio, but possessing different amount of active metal, we observed a decrease of the activity for the lower Pd content $(9 \%$ $\mathrm{Ag}-1 \% \mathrm{Pd} / \mathrm{AlOOH}_{(\mathrm{CIMP})}$ vs $4.5 \% \mathrm{Ag}-0.5 \% \mathrm{Pd} / \mathrm{AlOOH}_{(\mathrm{CIMP})}$ from 92 to $\left.48 \%\right)$. This decrease was probably related with the lower accessibility of Pd. In the latter case no $\mathrm{CO}$ formation was however observed.

Table 3. FA decomposition over bimetallic catalysts synthesized by co-impregnation (CIMP) method with different composition.

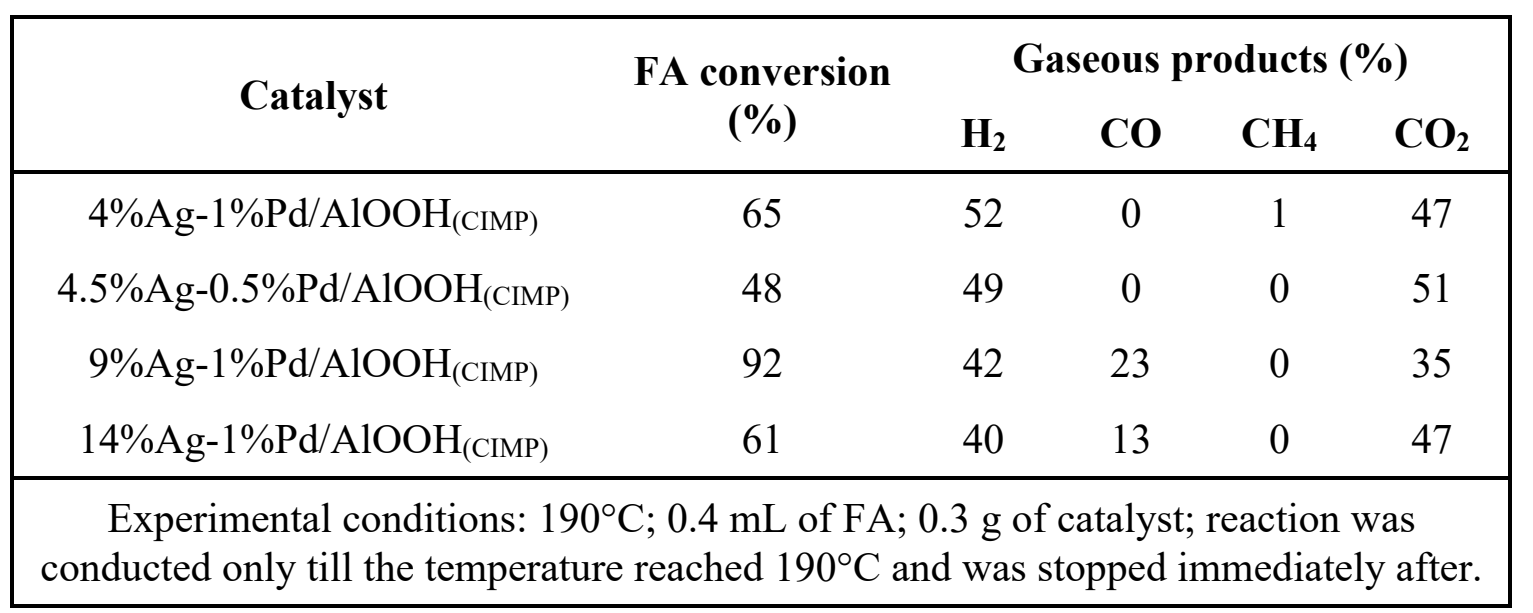

\subsection{Catalytic activity in LA hydrogenation}

Our main aim was to design selective catalysts for FA decomposition which at the same time will show good activity in the chosen hydrogenation process of LA into GVL. As shown before, Erreur! Signet non défini. one of the deciding factors for such a combined process is the presence of the $\mathrm{CO}$ which can easily poison the active metal, deactivating it for the following hydrogenation process. Consequently, we selected the catalyst showing the highest conversion in FA decomposition $\left(9 \% \mathrm{Ag}-1 \% \mathrm{Pd} / \mathrm{AlOOH}_{(\mathrm{CIMP})}\right)$. However, as higher selectivity was observed for $4 \% \mathrm{Ag}-1 \% \mathrm{Pd} / \mathrm{AlOOH}_{(\mathrm{CIMP})}$ catalyst, it was also included in further investigations. To start, we compared their activity to the one obtained by monometallic counterparts in the hydrogenation of LA with an external source of hydrogen (10 bar of $\left.\mathrm{H}_{2}\right)$ and then in the hydrogen transfer process from FA to LA. 


\subsubsection{With an external hydrogen source}

The catalytic tests in the hydrogenation reaction of LA in presence of 10 bar of $\mathrm{H}_{2}$ are reported in Table 4. The pressure of hydrogen was chosen to match the conditions reached by FA decomposition. Similarly to FA conversion tests (see Table 1), 5\% Pd/AlOOH was more active than $5 \% \mathrm{Ag} / \mathrm{AlOOH}$, with LA conversion of $39 \%$ and a GVL yield of $36 \%$. This activity did not drop dramatically when switching to bimetallic catalysts: a LA conversion of $35 \%$ was reported for $4 \% \mathrm{Ag}-1 \% \mathrm{Pd}$, while a more significant decrease was observed for a higher silver content with a $21 \%$ conversion for the $9 \% \mathrm{Ag}-1 \% \mathrm{Pd}$.

Table 4. LA hydrogenation with external source of hydrogen over mono- and bimetallic catalysts

\begin{tabular}{|ccc|}
\hline Catalyst & $\begin{array}{c}\text { LA conversion } \\
(\mathbf{\%})\end{array}$ & $\begin{array}{c}\text { GVL yield } \\
(\%)\end{array}$ \\
\hline $5 \% \mathrm{Ag} / \mathrm{AlOOH}$ & 4 & 3 \\
$5 \% \mathrm{Pd} / \mathrm{AlOOH}$ & 39 & 36 \\
$4 \% \mathrm{Ag}-1 \% \mathrm{Pd} / \mathrm{AlOOH}(\mathrm{CIMP})$ & 35 & 31 \\
$9 \% \mathrm{Ag}-1 \% \mathrm{Pd} / \mathrm{AlOOH}_{(\mathrm{CIMP})}$ & 21 & 20 \\
\hline Experimental conditions: $190^{\circ} \mathrm{C} ; 2 \mathrm{~h} ; 10$ bar $_{2} ; 1.0$ g of LA; 0.3 g of catalyst. \\
\hline
\end{tabular}

\subsubsection{With an internal hydrogen source}

Next, the same four catalysts were evaluated in the hydrogen transfer reaction from combined reaction of FA decomposition towards hydrogen and its direct use for LA hydrogenation (Table 5). In all cases, a 100\% conversion of FA was reached, showing that this first step is not significantly hampered by the presence of LA. The $4 \% \mathrm{Ag}-1 \% \mathrm{Pd} / \mathrm{AlOOH}$ gave $34 \%$ of LA conversion and $32 \%$ of GVL yield, which was significantly higher in comparison to both monometallic catalyst or the other bimetallic catalyst. The lack of the activity in the case of $9 \% \mathrm{Ag}-1 \% \mathrm{Pd} / \mathrm{AlOOH}$ was probably related to the formation of large amount of $\mathrm{CO}$, which was observed in FA decomposition described previously (Table 3).

Additionally, recyclability tests have been performed for the most active catalyst, i.e. 4\%Ag$1 \% \mathrm{Pd} / \mathrm{AlOOH}_{(\mathrm{CIMP})}$, both in FA decomposition and in FALA reaction (Tables S2-S4). As 
main result, it was shown that in FALA, full FA conversion was obtained in all cycles, whereas a high LA conversion was nearly maintained up to the third cycle. Only in the 4th test cycle, a significant decrease was observed. More details concerning this issue are provided in SI.

Table 5. LA hydrogenation using FA as an internal source of hydrogen over mono and bimetallic catalysts synthesized by co-impregnation method.

\begin{tabular}{|cccc|}
\hline Catalyst & FA conversion & $\begin{array}{c}\text { LA conversion } \\
(\%)\end{array}$ & GVL yield \\
\hline $5 \% \mathrm{Ag} / \mathrm{AlOOH}$ & 100 & 12 & 7 \\
$5 \% \mathrm{Pd} / \mathrm{AlOOH}$ & 100 & 4 & 1 \\
$4 \% \mathrm{Ag}-1 \% \mathrm{Pd} / \mathrm{AlOOH}(\mathrm{CIMP})$ & 100 & 34 & 32 \\
$9 \% \mathrm{Ag}-1 \% \mathrm{Pd} / \mathrm{AlOOH}_{(\mathrm{ClMP})}$ & 100 & 1 & 0 \\
\hline Experimental conditions: $190^{\circ} \mathrm{C} ; 5 \mathrm{~h} ; 1.0 \mathrm{~g}$ of LA; $0.4 \mathrm{~mL}$ of $\mathrm{FA} ; 0.6 \mathrm{~g}$ of catalyst; \\
\hline
\end{tabular}

\section{Characterization of the catalysts}

The results of the study of physicochemical properties of different Ag-Pd catalysts are presented in Table S1. The obtained data exhibit that the surface area was not affected significantly by the temperature treatment of the catalyst nor by the preparation method used. In most cases, the BET surface area ranged between $95-114 \mathrm{~m}^{2} / \mathrm{g}$ and was only slightly lower than the one noted for $\mathrm{AlOOH}\left(123 \mathrm{~m}^{2} / \mathrm{g}\right)$. In consequence, similar values for the pore volume and radius were observed.

\subsection{Surface analysis by ToF-SIMS of the catalysts}

The ToF-SIMS measurements were performed in order to determine the differences in metals and chlorine contents at the surface of the catalysts. The results presented in Table 6 revealed that the preparation method has a strong influence on the surface composition. For catalysts with the same composition $(4 \% \mathrm{Ag}-1 \% \mathrm{Pd})$, the lowest $\mathrm{Pd}^{+} / \mathrm{Ag}^{+}$surface ratio was noted in the case of $4 \% \mathrm{Ag}-1 \% \mathrm{Pd} / \mathrm{AlOOH}_{(\mathrm{CIMP})}$ catalyst. This can be explained by the good dispersion of 
$\mathrm{Pd}$ at the surface, which is related with the high intensity of the $\mathrm{Ag}^{+}$ion. ${ }^{54}$ This result was accompanied by the highest intensity of $\mathrm{PdAg}^{+}$ions suggesting the formation of an alloy or some specific interactions between metals. Both $4 \% \mathrm{Ag}-1 \% \mathrm{Pd} / \mathrm{AlOOH}_{(\mathrm{SIMP})}$ and $4 \% \mathrm{Ag}-$ $1 \% \mathrm{Pd} / \mathrm{AlOOH}_{(\mathrm{SIMP}-\mathrm{CR})}$ catalysts displayed similar $\mathrm{Pd}^{+} / \mathrm{Ag}^{+}$and $\mathrm{PdAg}^{+}$ion intensities, suggesting also the possible presence of an alloy. For them the highest Pd contribution in respect to $\mathrm{Ag}$ was identified on the surface. Further, the $4 \% \mathrm{Ag}-1 \% \mathrm{Pd} / \mathrm{AlOOH}_{\text {(SIMP-CR) }}$ catalyst exhibited the lowest intensities of ions which origin from metals, suggesting the smallest dispersion of the metals on the surface.

Table 6. Normalized intensity of selected ions calculated on the basis of the mass spectra collected from the surface of selected $\mathrm{Ag}-\mathrm{Pd} / \mathrm{AlOOH}$ catalysts

\begin{tabular}{|c|c|c|c|c|c|c|c|c|}
\hline \multirow[b]{2}{*}{ Catalyst } & \multirow{2}{*}{$\begin{array}{l}\text { Catalysts } \\
\text { preparation } \\
\text { method }\end{array}$} & \multicolumn{7}{|c|}{ Normalized ion intensities } \\
\hline & & $\begin{array}{l}\mathrm{Ag}^{+} \\
\times 10^{-2}\end{array}$ & $\begin{array}{l}\mathrm{Pd}^{+} \\
\times 10^{-4}\end{array}$ & $\begin{array}{r}\mathrm{Pd}^{+} / \mathrm{Ag}^{+} \\
\times 10^{-2}\end{array}$ & $\begin{array}{l}\mathrm{PdAg}^{+} \\
\mathrm{x} 10^{-4}\end{array}$ & $\begin{array}{l}\mathrm{Cl}^{-} \\
\times 10^{-1}\end{array}$ & $\begin{array}{l}\mathrm{AgCl}^{-} \\
\times 10^{-3}\end{array}$ & $\begin{array}{l}\mathrm{PdCl}^{-} \\
\times 10^{-4}\end{array}$ \\
\hline \multirow{3}{*}{$4 \% \mathrm{Ag}-1 \% \mathrm{Pd} / \mathrm{AlOOH}$} & CIMP & 3.0 & 4.1 & 1.4 & 1.9 & 1.6 & 1.7 & 8.5 \\
\hline & SIMP & 1.4 & 5.6 & 4.1 & 0.9 & 1.3 & 0.9 & 5.8 \\
\hline & SIMP-CR & 0.9 & 3.5 & 3.8 & 1.0 & 1.3 & 0.9 & 4.7 \\
\hline $\begin{array}{c}\text { 4.5\%Ag- } \\
0.5 \% \mathrm{Pd} / \mathrm{AlOOH}\end{array}$ & \multirow{3}{*}{ CIMP } & 3.3 & 3.7 & 1.1 & 1.8 & 2.0 & 1.9 & 8.1 \\
\hline $9 \% \mathrm{Ag}-1 \% \mathrm{Pd} / \mathrm{AlOOH}$ & & 3.9 & 3.3 & 0.9 & 2.0 & 2.1 & 2.2 & 9.0 \\
\hline $14 \%$ Ag-1\%Pd/AlOOH & & 6.5 & 1.0 & 0.2 & 4.5 & 2.3 & 4.6 & 15.0 \\
\hline
\end{tabular}

An analysis of the mass spectra of the catalysts containing different percentage of metals (prepared via CIMP method) showed obviously increasing amount of Ag on the surface with the higher Ag loading. This was associated with the increasing amount of the possible alloy or strong interaction of $\mathrm{Pd}-\mathrm{Ag}$ (observed as $\mathrm{PdAg}^{+}$ion intensity increase).

In addition, the chlorine residue was identified on the surface of the analyzed catalysts. Its amount was increasing for the catalysts containing more silver in the composition. Chlorine was associated both with $\mathrm{Ag}$ and $\mathrm{Pd}$. Interestingly the highest Ag presence stimulated the highest chlorine affinity to the surface, and triggered the formation of $\mathrm{PdCl}_{\mathrm{x}}$ and $\mathrm{AgCl}_{\mathrm{x}}$ species. This was visible for both catalysts containing the same composition $4 \% \mathrm{Ag}-1 \%$ $\mathrm{Pd} / \mathrm{AlOOH}$ but prepared by different methods (CIMP vs SIMP) or containing different Ag content (14 vs $9 \mathrm{wt} \%)$. 


\subsection{XRD analysis of the investigated catalysts}

The diffraction patterns of the monometallic and bimetallic catalysts are shown in Figure 1. The well-resolved diffraction peaks of the $\mathrm{AlOOH}$ support (Figure 1a) are visible at $2 \theta=$ $14.4^{\circ}, 28.2^{\circ}, 38.3^{\circ}, 44.4^{\circ}, 48.8^{\circ}, 49.2^{\circ}, 64.0^{\circ}$ and $64.7^{\circ}$ for the (020), (120), (031), (131), (051), (200), (231), (002) planes (JCPDS 01-083-1506). For the 5\%Pd/AlOOH monometallic catalyst additional diffraction signals have been observed at $2 \theta=40.1^{\circ}, 46.7^{\circ}$ and $82.0^{\circ}$, and assigned to the diffraction of (111), (200) and (311) planes of metallic tetragonal Pd nanoparticles, respectively (JCPDS 05-0681). In the case of the 5\% Ag/AlOOH catalyst, the diffraction lines at $2 \theta=38.1^{\circ}, 44.3^{\circ}, 64.4^{\circ}, 77.5^{\circ}$ and $81.5^{\circ}$ were assigned to the (111), (200), (220), (311) and (222) planes of metallic cubic Ag particles, respectively (JCPDS 04-0783). Additionally, for the bimetallic catalysts the diffraction peaks related to $\mathrm{AgCl}$ were observed. The diffraction signals at $2 \theta=27.8^{\circ}, 32.3^{\circ}, 46.3^{\circ}, 54.9^{\circ}$ and $57.6^{\circ}$ were assigned to the respective (111), (200), (220), (311) and (222) planes of AgCl (JCPDS 01-1013). This can be associated with the preparation procedure of catalyst, and related to presence of $\mathrm{Pd}$ precursor which constitute the source of chlorine. Also, in the case of $4 \% \mathrm{Ag}-1 \% \mathrm{Pd} / \mathrm{AlOOH}_{(\mathrm{CIMP})}$ a slight broadening of the signals between $\mathrm{Ag}$ and $\mathrm{Pd}\left(2 \theta=38.1^{\circ}\right.$ and $40.1^{\circ}$, respectively $)$ is observed. This broad signal might indicate the possible interaction between Pd and Ag. ${ }^{55,56}$

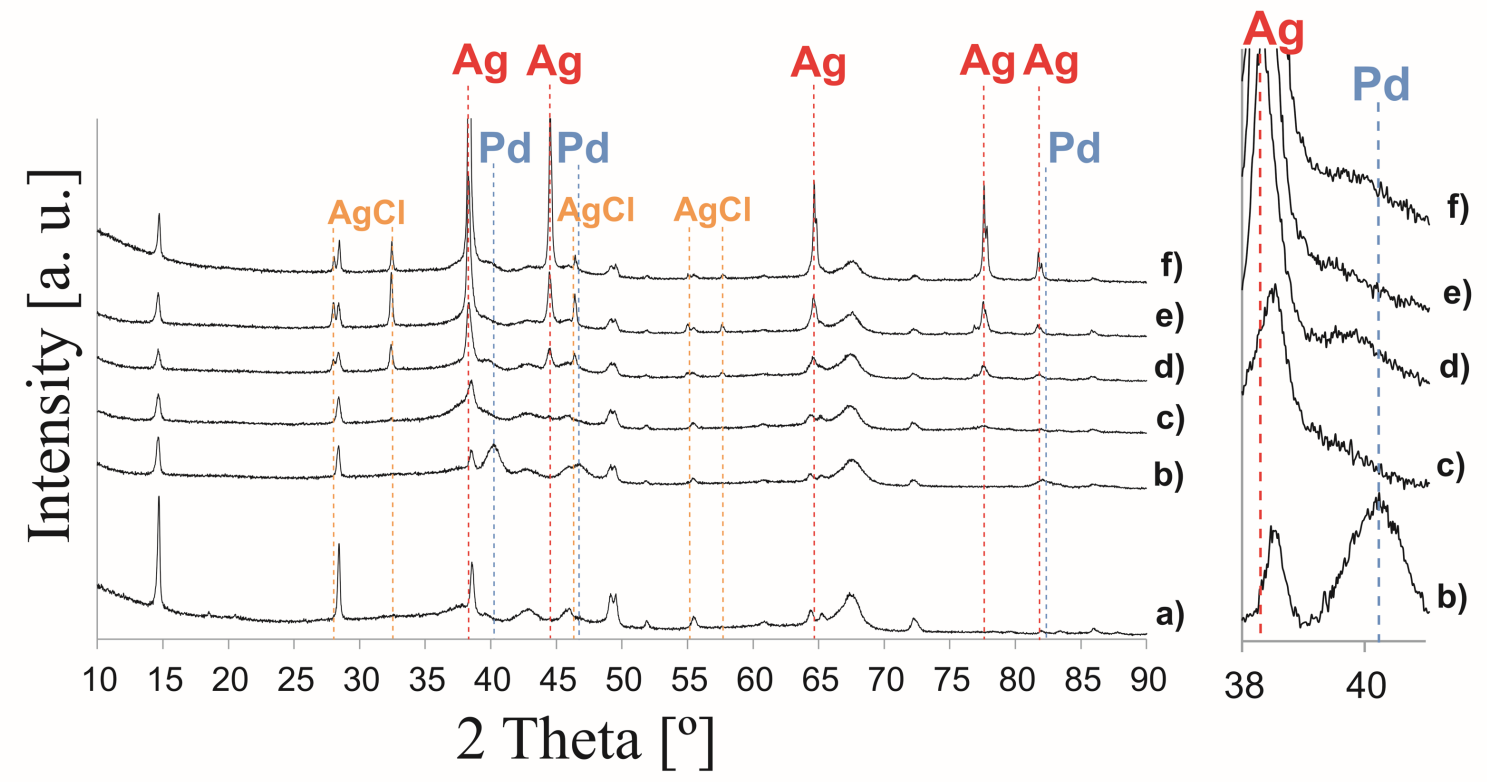

Figure 1. XRD patterns of (a) $\mathrm{AlOOH}$ support, (b) $5 \% \mathrm{Pd} / \mathrm{AlOOH}$ and (c) $5 \% \mathrm{Ag} / \mathrm{AlOOH}$ monometallic and (d) $4 \% \mathrm{Ag}-1 \% \mathrm{Pd} / \mathrm{AlOOH}_{(\mathrm{CIMP})}$, (e) $9 \% \mathrm{Ag}-1 \% \mathrm{Pd} / \mathrm{AlOOH}_{(\mathrm{CIMP})}$ and (f) 
$14 \% \mathrm{Ag}-1 \mathrm{Pd} / \mathrm{AlOOH}_{(\mathrm{CIMP})}$ bimetallic catalysts. By dashed vertical lines the $2 \theta$ values for: $\mathrm{AgCl}$ in orange, $\mathrm{Ag}$ in red and $\mathrm{Pd}$ in blue are marked.

\subsection{TPR analysis of the catalysts}

The TPR profiles for selected mono- and bimetallic catalysts are presented in Figure 2. In the case of monometallic Ag catalyst one wide irregular peak was identified within a broad temperature range $\left(50^{\circ} \mathrm{C}-280^{\circ} \mathrm{C}\right)$ and with two maxima at $95^{\circ} \mathrm{C}$ and $194^{\circ} \mathrm{C}$. This can be related to the reduction of $\mathrm{AgO}_{\mathrm{x}}$ oxides or $\left(\mathrm{Ag}_{2} \mathrm{O}\right)_{3} \mathrm{AgNO}_{3}$ species. ${ }^{57,58,59,60}$ The TPR profiles of monometallic $5 \% \mathrm{Pd} / \mathrm{AlOOH}$ exhibits typical behavior for palladium catalysts. The negative peak with maximum at $62^{\circ} \mathrm{C}$ corresponds to the decomposition of palladium hydride $(\beta-\mathrm{PdH})$ which was formed upon absorption of hydrogen in metallic palladium. This behavior was not observed in the case of bimetallic catalysts. The absence of negative reduction peak could be related to the presence of smaller Pd particles ${ }^{61,62}$ or this behavior may be connected with the presence of chlorine ions adsorbed on the catalysts surface, as formation of the hydride depends as well on the nature of the Pd support interface. ${ }^{63}$

For all Ag-Pd catalysts two reduction ranges were identified. For catalysts having a low silver loading (4 and 9\%), the low temperature reduction peak is found around $140^{\circ} \mathrm{C}$ and may be associated with the reduction of $\mathrm{AgO}_{\mathrm{x}}$ not containing chlorine and possibly $\mathrm{PdO}_{\mathrm{x}}$ species. Hydrogen consumption appears in a similar region for both cases, therefore, the reduction of Ag-Pd species cannot be excluded. ${ }^{59,60}$ The slight temperature difference can be related to the different particle size presence and by this different interaction with the support. For $14 \% \mathrm{Ag}-$ $1 \% \mathrm{Pd}$, the TPR profile is clearly different in the low temperature range with a peak at $83^{\circ} \mathrm{C}$. Due to the very high metal loading, the formation of large particles is more likely, and these particles would interact weaker with the support, explaining the easiest reduction. For all catalysts, the high temperature peak showed a similar maximum around $400^{\circ} \mathrm{C}$ suggesting similarities in the formed species. It differs only in the hydrogen uptake intensity which is the lowest for $4 \% \mathrm{Ag}-1 \% \mathrm{Pd}$ and increases with the $\mathrm{Ag}$ loading. We hypothesize that this signal may be related with the reduction of silver $\mathrm{AgO}_{\mathrm{x}} \mathrm{Cl}_{\mathrm{y}}$ species associated with chlorine. Those species could be formed in situ during the catalysts preparation. Longer TPR measurements were also performed $\left(400^{\circ} \mathrm{C}\right.$ duration of $\left.1 \mathrm{~h}\right)$ and they showed that after this time there is no more hydrogen consumption, justifying the choice of $400^{\circ} \mathrm{C}$ as the catalysts reduction temperature. 


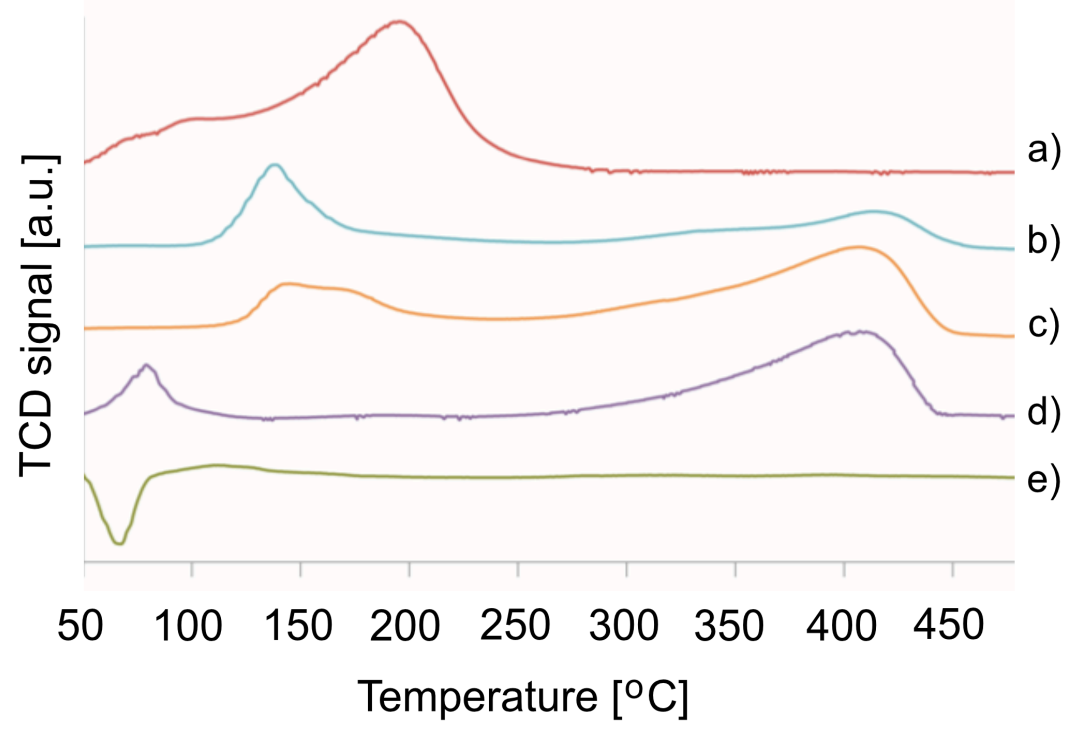

Figure 2. Temperature programmed reduction profiles of the investigated catalysts: (a) $5 \% \mathrm{Ag} / \mathrm{AlOOH}$, (b) $4 \% \mathrm{Ag}-1 \% \mathrm{Pd} / \mathrm{AlOOH}$, (c) $9 \% \mathrm{Ag}-1 \% \mathrm{Pd} / \mathrm{AlOOH}$, (d) $14 \% \mathrm{Ag}-$ $1 \% \mathrm{Pd} / \mathrm{AlOOH},(\mathrm{e}) 5 \% \mathrm{Pd} / \mathrm{AlOOH}$.

\subsection{XPS surface investigation of the catalysts}

Figure 3 shows the Pd 3d orbital region of the XPS spectra for the catalysts, while both the Ag $3 \mathrm{~d}$ orbital region and the wide scan survey spectra are reported in Figure S2. The Pd $3 \mathrm{~d}$ orbital XPS spectra for the monometallic Pd catalyst exhibited a main doublet contribution at 334.5 $\mathrm{eV}$ and $339.8 \mathrm{eV}$ (with a $3 \mathrm{~d}_{5 / 2}-3 \mathrm{~d}_{3 / 2}$ spin-orbit coupling constant of $5.26 \mathrm{eV}$ ) assigned to metallic Pd. The strong peak asymmetry resulted from the presence of higher doublet contributions at 336.3-341.6 eV and 338.7-344.0 eV. They were assigned respectively to the usual oxidized surface $\mathrm{Pd}$ species, and also to $\mathrm{Pd}$ atoms in interaction with residual chloride species (eg. as Pd oxychloride species, similarly to what has been already proposed for $\mathrm{Pd} / \mathrm{Al}_{2} \mathrm{O}_{3}$ or by analogy to $\mathrm{Al}_{2} \mathrm{O}_{3}$ and $\mathrm{C}$ supported $\mathrm{Ru}$ systems prepared with chloride precursors). ${ }^{\mathrm{XX}, 64,65}$ The presence of residual chlorine in sample was evidenced on the wide scan survey spectrum, in agreement with ToF-SIMS results. The available data do not allow to distinguish whether the additional peak corresponds to Pd oxide(s) or hydroxide(s). The value recorded for metallic $\mathrm{Pd}$ was about 0.5 to $1 \mathrm{eV}$ lower than the reported binding energies for bulk Pd, evidencing the existence of a metal-support interaction between the Pd nanoparticles and the support with charge transfer to the supported metal, as often observed for oxide supports. 
By contrast, the Pd 3d orbital spectra for the Ag-Pd bimetallic catalysts revealed only the presence of a single doublet contribution assigned to metallic $\mathrm{Pd}$, and no contributions corresponding to surface oxidized $\mathrm{Pd}$ or to $\mathrm{Pd}$ species in interaction with residual chlorine were observed. Further, the metallic Pd doublet contribution was shifted to lower binding energy when compared to the monometallic Pd counterpart catalyst, the stronger shift of 0-7$0.8 \mathrm{eV}$ being observed for both SIMP and CIMP catalysts with a 4:1 Pd:Ag ratio, and a shift of $0.4 \mathrm{eV}$ being observed for both higher Ag contents. This downward shift in the case of bimetallic Ag-Pd catalysts revealed the existence of $\mathrm{Pd}-\mathrm{Ag}$ intermetallic interactions. According to the electrostatic model, it results from the higher electronegativity of Pd vs. Ag and corresponds to an electronic enrichment of the metallic $\mathrm{Pd}$. This is in agreement with the work of Lamb et al. ${ }^{66}$ and with the observation of partial charge transfer from Ag to Pd ${ }^{67,68}$. This electronic enrichment might explain the stronger resistance of Pd to surface oxidation observed for AgPd bimetallic catalysts whatever the Pd:Ag ratio. In a mirrored reversed manner, the corresponding electronic depletion of $\mathrm{Ag}$ in the bimetallic catalysts compared to the monometallic Ag counterpart was evidenced by the $0.3 \mathrm{eV}$ upward shift of the binding energy assigned to metallic Ag in the Ag 3d orbital spectra (from $366.5 \mathrm{eV}$ to $c a .366 .9 \mathrm{eV}$ whatever the Pd:Ag ratio), although less pronounced than for Pd due to the excess of $\mathrm{Ag} v s$. Pd (Fig. S2). 


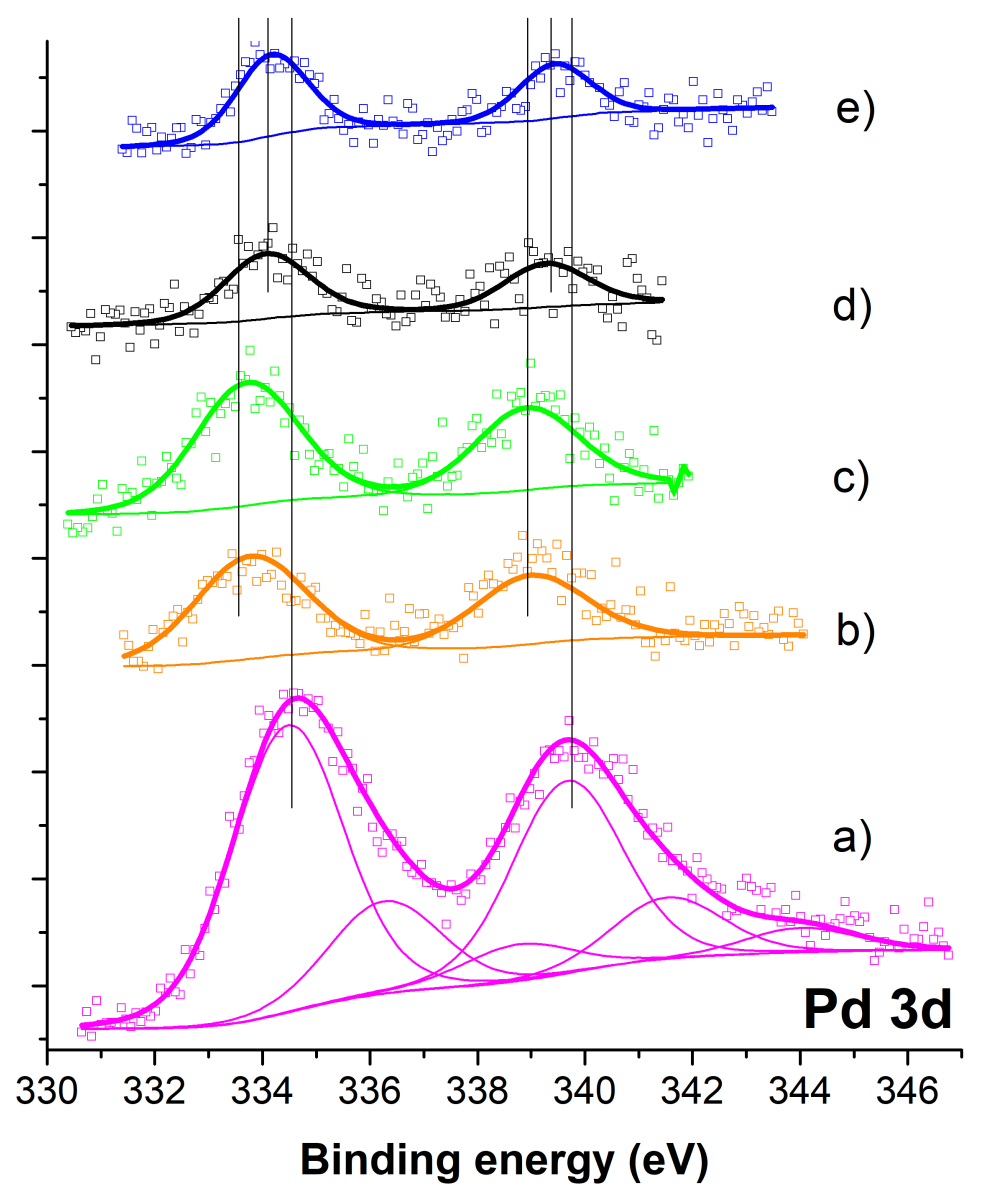

Figure 3. XPS Pd 3d core orbital spectra recorded for the catalysts with a) $5 \% \mathrm{Pd}$, b) $4 \% \mathrm{Ag}$ $1 \% \mathrm{Pd}(\mathrm{CIMP})$, c) 4\% Ag-1\%Pd (SIMP), d) 9\% Ag-1\%Pd and e) 14\% Ag-1\%Pd.

In addition, the catalysts with the higher Ag:Pd bulk ratio of 9:1 and 14:1 were characterized by $\mathrm{Ag} / \mathrm{Pd}$ surface atomic ratios of 82 and 48 , respectively, far higher than their respective bulk values. This indicated a very pronounced sub-concentration of $\mathrm{Pd}$ at the surface of the bimetallic catalysts. By contrast, both $4 \% \mathrm{Ag}-1 \% \mathrm{Pd} / \mathrm{AlOOH}(\mathrm{CIMP})$ and $4 \% \mathrm{Ag}-1 \%$ $\mathrm{Pd} / \mathrm{AlOOH}_{(\mathrm{SIMP})}$ catalysts behave differently, and displayed a $\mathrm{Ag} / \mathrm{Pd}$ surface atomic ratio of 1.8 and 1.6, respectively, slightly lower than the bulk ratio of 4 . This indicated a slight overconcentration of Pd at the surface of the bimetallic catalysts, that however remained composed of Pd atoms dispersed in the $\mathrm{Ag}$ atom network. 


\section{DFT investigations of FA decomposition}

As underlined in section 3, the activity and selectivity of FA dehydrogenation is crucial for the LA hydrogenation using FA as an internal hydrogen source. To provide a better rational, the FA reactivity was investigated by periodic DFT using slab models of $\operatorname{Ag}(111), \operatorname{Pd}(111)$ and Pd-Ag(111) surfaces. It is well known that FA can either be dehydrogenated yielding $\mathrm{H}_{2}$ and $\mathrm{CO}_{2}$, either be dehydrated yielding $\mathrm{CO}$ and $\mathrm{H}_{2} \mathrm{O} .{ }^{69}$ The general mechanism is represented in Scheme 1 and contains two main routes. The first one starts with the O-H scission and produces adsorbed formate $\mathrm{HCOO}$. It adsorbs preferentially in a bidentate mode, $\mathrm{HCOO}_{\mathrm{B}}$, by two $\mathrm{O}$ atoms. For its further decomposition, it needs to rotate and reach the monodentate mode ( $\mathrm{HCOO}_{\mathrm{M}}$, adsorbed via $\mathrm{O}$ and $\mathrm{H}$ atoms), in which the $\mathrm{C}-\mathrm{H}$ is more likely to break since it points towards the metallic surface. The second route, starts with $\mathrm{C}-\mathrm{H}$ dissociation and yields to the carboxyl intermediate $\mathrm{COOH}$. This is a branching point between dehydrogenation (subsequent $\mathrm{O}-\mathrm{H}$ scission) and dehydration (following $\mathrm{C}-\mathrm{OH}$ scission). Last, if the dehydration steps are equilibrated, the water gas shift reaction may occur, converting $\mathrm{CO}$ and $\mathrm{H}_{2} \mathrm{O}$ into the more stable $\mathrm{CO}_{2}$ and $\mathrm{H}_{2}$ products through the carboxyl intermediate (and maybe also FA and formate), opening another channel to produce the desired $\mathrm{H}_{2}$.

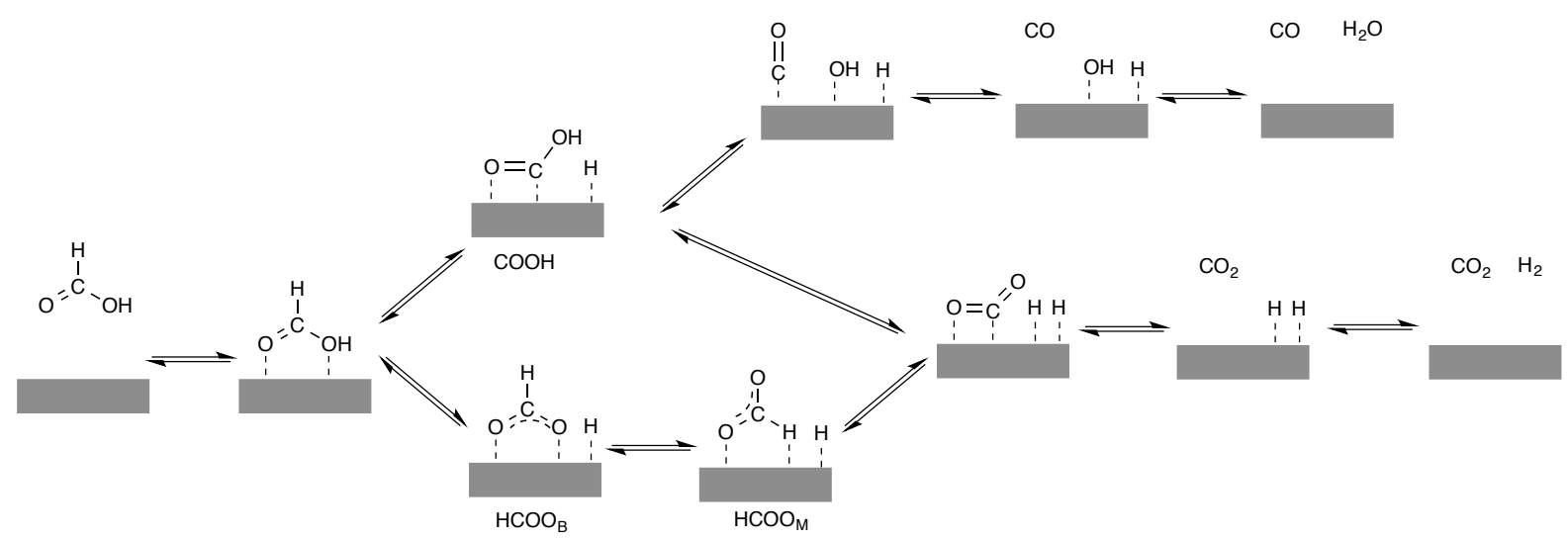

Scheme 1. FA ( $\mathrm{HCOOH})$ dehydrogenation and dehydration mechanisms

These pathways were considered on monometallic $\operatorname{Ag}(111)$ and $\operatorname{Pd}(111)$ surfaces, and on two bimetallic systems: Ag@Pd, that can model a core@shell structure, with 1 layer of Pd over 3 layers of $\mathrm{Ag}$ and $1 \mathrm{Pd}-\mathrm{Ag}$ with an isolated $\mathrm{Pd}$ atom in the topmost layer surrounded by $\mathrm{Ag}$, modelling a diluted Pd alloy with Ag. (For the unit cell structures see Figure S1.) The bimetallic systems were chosen to explain the difference in activity observed experimentally 
between the catalysts exposing more Pd on the surface (core@shell model in the computations) and catalysts containing more Pd-Ag alloy sites (model with one $\mathrm{Pd}$ atom surrounded by Ag).

\subsection{The formate pathway}

The formate pathway is the most likely path to produce $\mathrm{H}_{2}$ and $\mathrm{CO}_{2}$. The corresponding Gibbs energy profiles are shown in Figure 4, comparing the four model surfaces.

On $\operatorname{Ag}(111)$ (shown in grey), the adsorption of most molecules and intermediates is endergonic, with the exception of FA $(-0.23 \mathrm{eV})$. The high scissions barriers (above $0.90 \mathrm{eV}$ ) together with high energy span $(1.27 \mathrm{eV})$ yield to a low activity predicted for Ag catalysts. In contrast, FA, intermediates and $\mathrm{H}_{2}$ are strongly chemisorbed on $\mathrm{Pd}(111)$. The $\mathrm{O}-\mathrm{H}$ scission is easy with a barrier of $0.31 \mathrm{eV}$ and the overall process is limited by the strong adsorption of $\mathrm{HCOO}_{\mathrm{B}}$ (see blue profile). Its rotation to $\mathrm{HCOO}_{\mathrm{M}}$ is thermodynamically demanding $(0.66 \mathrm{eV})$ and thus the $\mathrm{C}-\mathrm{H}$ scission requires an overall barrier of $0.70 \mathrm{eV}$, which is also the overall barrier of the reaction (see insets on Figure 4 for a representation of the structure of this transitions state). This clearly indicates that $\mathrm{Pd}$ is predicted being active. However, the rather strong adsorption of $\mathrm{H}_{2}(-0.34 \mathrm{eV}$ per hydrogen atom) may be a source of surface poisoning, limiting the overall activity with the pressure of hydrogen building up.

Let us turn now to alloy models. The core@shell model (Ag@Pd, green labels) exhibits a behavior that is very close to $\mathrm{Pd}$, but with a noticeably higher overall barrier ( $0.77 \mathrm{eV}$ vs. 0.70 $\mathrm{eV})$ and a stronger adsorption of $\mathrm{H}_{2}(-0.42 \mathrm{eV}$ vs. $-0.34 \mathrm{eV})$, due to the strain imposed by the underlying Ag. When diluting Pd in a large excess of Ag, a Pd-Ag alloy can be formed that shows several types of sites such as isolated Pd, labeled here 1Pd-Ag. On this surface, the energy landscape is strongly modified, with a profile (in red) lying in between the one of $\mathrm{Ag}$ and the ones of Pd and $\mathrm{Ag} @ \mathrm{Pd}$. The energy difference between $\mathrm{HCOO}_{\mathrm{B}}$ and $\mathrm{HCOO}_{\mathrm{M}}$ is equal to $0.70 \mathrm{eV}$ and the energy span of the path is $0.93 \mathrm{eV}$, hence higher than the ones on $\mathrm{Pd}(0.70$ $\mathrm{eV})$ and on the core@shell model $(0.77 \mathrm{eV})$. This is detrimental to a high activity, but may be compensated by an exergonic desorption of $\mathrm{H}_{2}$, yielding to more sites available to perform the dehydrogenation of FA. Indeed, hydrogen atom is chemisorbed by $0.09 \mathrm{eV}$, and this implies a short residence time on the metallic surface. 


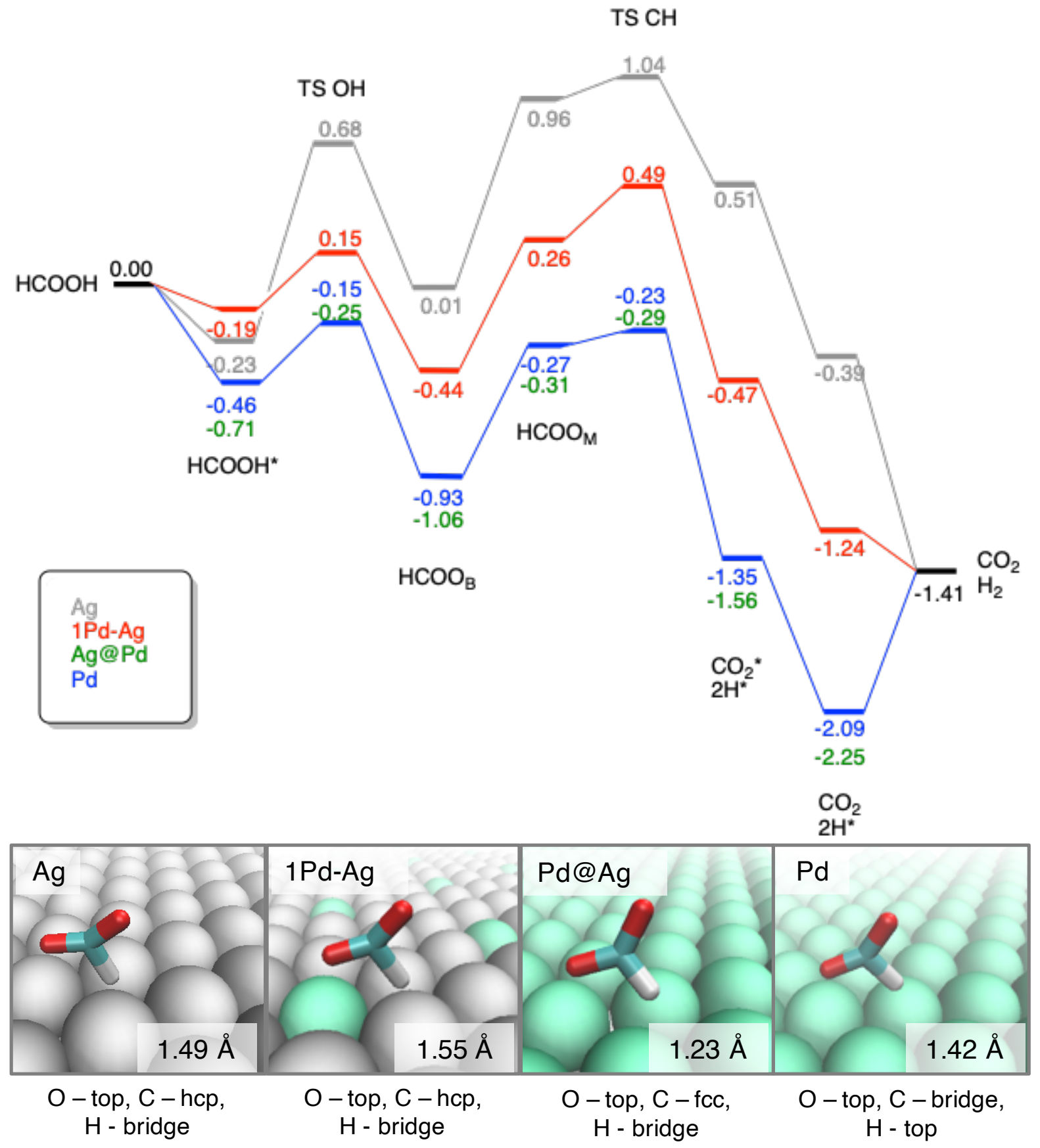

Figure 4. Gibbs free energy profiles for FA $(\mathrm{HCOOH})$ decomposition via formate path at $190^{\circ} \mathrm{C}$ (in eV) on $\mathrm{Ag}(111)$ (grey), alloys model 1Pd-Ag (red) and $\mathrm{Ag} @ \mathrm{Pd}$ (green), and Pd(111) (blue). Adsorbed species are labeled with a “*”. Insets are showing the structure of the C-H scission transition state on $\mathrm{Ag}(111), 1 \mathrm{Pd}-\mathrm{Ag}, \mathrm{Ag} @ \mathrm{Pd}$ and Pd(111) surfaces.

\subsection{The carboxyl pathway}

The carboxyl pathway is systematically less likely than the formate path to produce $\mathrm{H}_{2}$ (higher lying transition state for the $\mathrm{C}-\mathrm{H}$ scission and/or the following $\mathrm{O}-\mathrm{H}$ scission). However, it is 
critical regarding the $\mathrm{CO}$ production and the subsequent possibility of poisoning. The corresponding Gibbs energy profiles are shown in Figure 5, the branching towards $\mathrm{CO}$ production being shown with dashed lines.

On $\operatorname{Ag}(111)$, the carboxyl intermediate $\mathrm{COOH}$ is less likely to be reached than the formate $\mathrm{HCOO}_{\mathrm{B}}$ : first, the $\mathrm{C}-\mathrm{H}$ scission requires a higher input of energy than $\mathrm{O}-\mathrm{H}(0.50 \mathrm{eV}$ more $)$ and second, the carboxyl is less stable by $1.02 \mathrm{eV}$. Thus, generating $\mathrm{H}_{2}$ or $\mathrm{CO}$ is very unlikely through this route on Ag. Similarly, on Pd(111), the carboxyl pathway is less likely than the formate one to produce $\mathrm{H}_{2}$ since the transition state of C-H scission is lying higher in energy. However, $\mathrm{HCOO}_{\mathrm{B}}$ is slightly less stable than the carboxyl $\mathrm{COOH}$. From $\mathrm{HCOO}_{\mathrm{B}}$ the backward reaction to $\mathrm{COOH}$ has an overall barrier of $0.96 \mathrm{eV}$ to be compared with its forward conversion to $\mathrm{CO}_{2}$ and $\mathrm{H}_{2}$ that necessitates an energy input of only $0.70 \mathrm{eV}$. As a consequence, $\mathrm{COOH}$ production flux will be small, but, once this intermediate is reached, the branching towards $\mathrm{CO}$ is easy. Indeed, the C-OH scission barrier is only of $0.46 \mathrm{eV}$ (vs. $0.56 \mathrm{eV}$ for the $\mathrm{O}-\mathrm{H}$ ) and $\mathrm{CO}$ is strongly chemisorbed, likely to poison the surface $\left(\Delta \mathrm{G}_{\mathrm{des}}=+1.05 \mathrm{eV}\right)$. The overall picture is the same for the core@shell model Ag@Pd but not for the isolated Pd (1Pd-Ag). In the later case, the carboxyl intermediate $\mathrm{COOH}$ is slightly less stable than the formate $\mathrm{HCOO}_{\mathrm{B}}$ (by $0.05 \mathrm{eV}$ ) but is easier to reach than on $\mathrm{Pd}$ and $\mathrm{Ag} @ \mathrm{Pd}$, with a barrier of only $0.67 \mathrm{eV}$ to isomerize $\mathrm{HCOO}_{\mathrm{B}}$ into $\mathrm{COOH}$. Then, the $\mathrm{O}-\mathrm{H}$ scission in $\mathrm{COOH}$ is particularly hard with a barrier of $0.96 \mathrm{eV}$ while the $\mathrm{C}-\mathrm{OH}$ scission is very easy $(0.43 \mathrm{eV})$, yielding to a massive production of $\mathrm{CO}$ from $\mathrm{COOH}$. In addition, adsorption of $\mathrm{CO}$ is only slightly exergonic $\left(\Delta \mathrm{G}_{\mathrm{ads}}\right.$ $=-0.1 \mathrm{eV}$ ) since it is hardly stabilized. The weak interaction of $\mathrm{CO}$ with $1 \mathrm{Pd}-\mathrm{Ag}$ results from the very weak interaction of $\mathrm{CO}$ with $\mathrm{Ag}$ and the limited interaction of $\mathrm{CO}$ with the isolated $\mathrm{Pd}$, compared with Pd surfaces, since it can build only one Pd-CO bond and not three (see Figure 5, CO adsorbs preferentially in top position on 1Pd-Ag at the Pd atom, while it adsorbs in a ternary site on other Pd-reach metal surfaces). This intermediate adsorption strength prevents CO poisoning. Last, the water gas shift (WGS) reaction is strongly facilitated on it with an overall barrier of only $1.03 \mathrm{eV}$. 

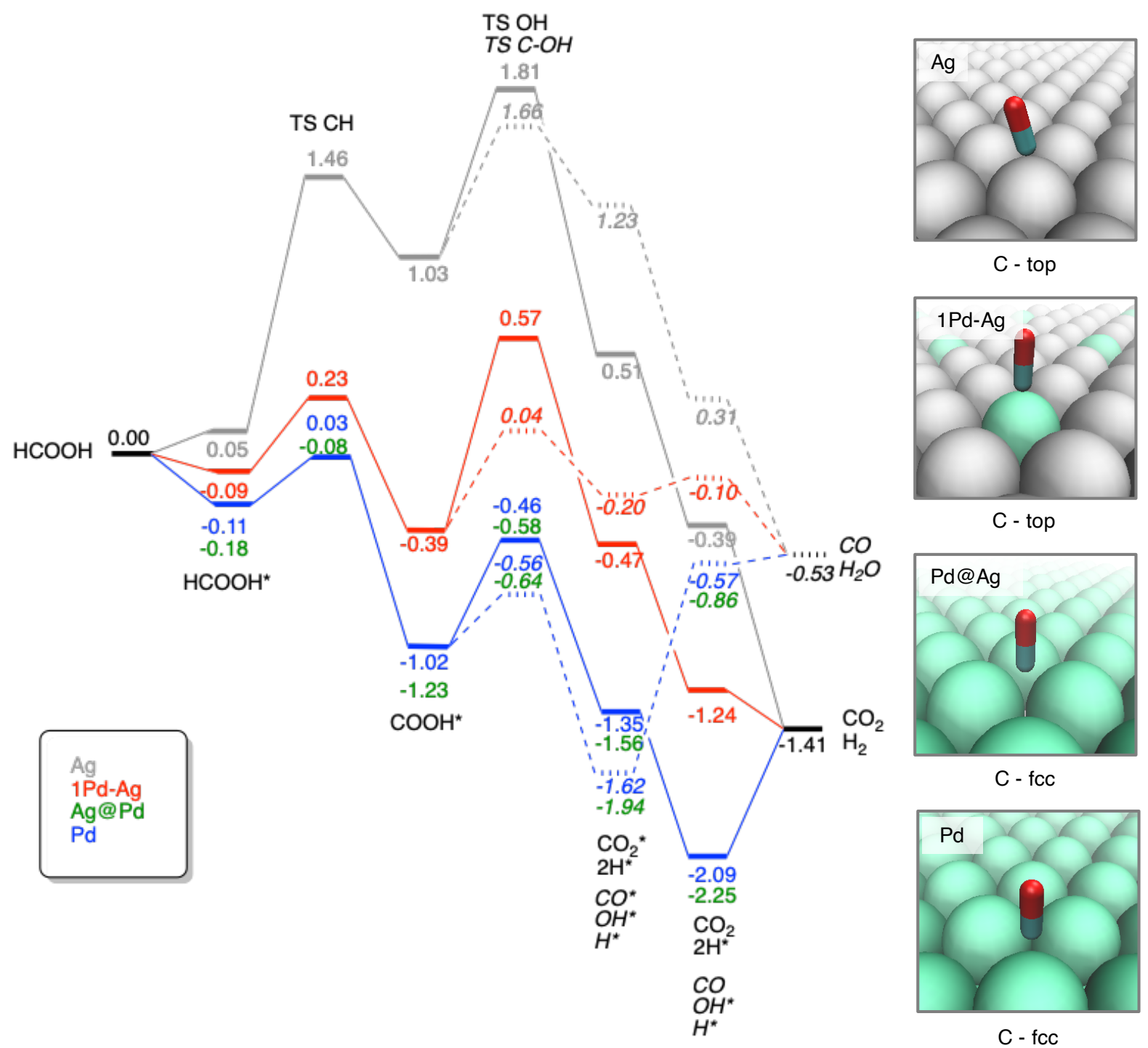

Figure 5. Gibbs free energy profiles for FA (HCOOH) decomposition via carboxyl path at $190^{\circ} \mathrm{C}$ (in eV) on $\mathrm{Ag}(111)$ (grey), alloys model 1Pd-Ag (red) $\mathrm{Ag} @ \mathrm{Pd}$ (green) and $\mathrm{Pd}(111)$ (blue). The dehydrogenation path is shown with a solid line and a straight font, while the dehydration path is shown with a dashed line and an italic font. Adsorbed species are labeled with a “*”. Insets are showing the structures of CO adsorbed at Ag(111), 1Pd-Ag, Ag@Pd, and $\operatorname{Pd}(111)$.

\subsection{A rational for the observed activity}

The values of energy spans for FA $(\mathrm{HCOOH})$ dehydrogenation via $\mathrm{HCOO}$, water-gas shift reaction and adsorption energies for $\mathrm{H}$ and $\mathrm{CO}$ species are collected in Table S5 for all the investigated surfaces. Based on the results, Ag is clearly predicted being not active in the production of $\mathrm{H}_{2}$ and $\mathrm{CO}_{2}$. In contrast, Pd and core@shell Pd-Ag (Ag@Pd) are very active 
through the formate pathway with a reaction energy span of $0.70 \mathrm{eV}$ and $0.78 \mathrm{eV}$, respectively. However, intermediates are strongly bonded and these catalysts risk to be poisoned by chemisorbed hydrogen and by accumulation of chemisorbed CO. Isolated Pd in Ag (1Pd-Ag) is less efficient in term of overall barrier $(0.93 \mathrm{eV})$, but the Gibbs free energy profile is much flatter and the metallic surface is thus less likely to be poisoned by intermediates (in particular $\mathrm{H})$. CO can be easily produced but it cannot block the surface and can be easily converted back to $\mathrm{H}_{2}$ through the WGS reaction. This process will be facilitated by the fact that water is here the solvent ${ }^{70}$ and later by the subsequent utilization of hydrogen to hydrogenate LA. Thus, this is why experimentally $4 \% \mathrm{Ag}-1 \% \mathrm{Pd} / \mathrm{AlOOH}$ is the best catalyst for the hydrogen transfer reaction from FA to LA.

\section{Conclusions}

In the quest of new green chemical processes, deeper understanding of catalytic processes is a corner stone, in particular when multiple reactions are involved such as in the hydrogenation of levulinic acid into gamma-valerolactone using formic acid as internal hydrogen source. Combining Ag and Pd, several metal-supported catalysts were prepared and characterized. To start, they were tested in the formic acid decomposition. The ones obtained by coimpregnation method showed the best activity. The dilution of $\mathrm{Pd}$ in $\mathrm{Ag}$ modified the activity and the selectivity: the $4 \% \mathrm{Ag}-1 \% \mathrm{Pd} / \mathrm{AlOOH}$ showed the best selectivity in formic acid decomposition, while the best activity was reached using the $9 \% \mathrm{Ag}-1 \% \mathrm{Pd} / \mathrm{AlOOH}$. These two bimetallic catalysts were selected together with monometallic counterparts and used to perform the levulinic acid hydrogenation into gamma-valerolactone. When using an external source of hydrogen, Pd and Ag-Pd alloys were all efficient, whereas when turning to the hydrogen transfer from formic acid to levulinic acid, only the 4\% Ag-1\% Pd showed a good activity. However, targeting a one-pot approach (FALA), the side dehydration route needs to be avoided to limit the poisoning of the metal supported catalysts by CO. Strong Ag-Pd interaction observed in the case of this bimetallic catalyst 4\% Ag-1\% Pd showed to have crucial role in catalytic performance in FALA process. Based on performed characterizations, several models were built and compare to rationalize the observed catalytic activity using periodic DFT computations. Pd is shown to be active, but prone to poisoning by $\mathrm{CO}$, which is limited on diluted $\mathrm{Pd}-\mathrm{Ag}$ alloy where the $\mathrm{CO}$ adsorption is very weak thanks to the isolation of $\mathrm{Pd}$ atoms. In addition, this site is efficient at catalyzing the water gas shift reaction, producing $\mathrm{H}_{2}$ that can be use in the hydrogenation of levulinic acid in the one-pot process. 


\section{Acknowledgements}

The authors declare no conflict of interest.

The authors would like to thank prof. Jacek Grams from Lodz University of Technology for the ToF-SIMS analysis. The DFT computations were performed thanks to the PSMN resources. Campus France is acknowledged for its financial support PHC Polonium for traveling.

\section{List of abbreviations}

FA - formic acid

LA - levulinic acid

GVL - gamma-valerolactone

CIMP - co-impregnation method

SIMP - subsequent impregnation method

CIMP-CR - co-impregnation method with chemical reduction

SIMP-CR - subsequent impregnation method with chemical reduction

WGS - water-gas shift reaction

TPR - Temperature-programmed reduction

XRD - X-ray diffraction

ToF-SIMS - Time-of-Flight Secondary Ion Mass Spectrometry

$\mathrm{ML}$ - monolayer

XPS - X-Ray Photoelectron Spectroscopy

\section{Supplementary material}

The supplementary material contains: physicochemical characterization data for the catalysts, $\mathrm{Ag} 3 \mathrm{~d}$ and wide scan survey XPS spectra for the catalysts, tests of catalyst recyclability in FA decomposition and FALA combined reaction, models of the surfaces used in DFT computations, table with the energy spans and adsorption values for chosen reaction pathways and reaction intermediates, cartesian coordinates of all the reaction species for the investigated surfaces. 
${ }^{1}$ Zhu Q-L, Xu Q. Liquid organic and inorganic chemical hydrides for high-capacity hydrogen storage. Energy Environ. Sci. 2015;8:478-512 https://doi.org/10.1039/C4EE03690E

${ }^{2} \mathrm{Yu}$ X, Pickup PG. Recent advances in direct formic acid fuel cells (DFAFC). J Pow Sour 2008;182:124-32 https://doi.org/10.1016/j.jpowsour.2008.03.075

${ }^{3} \mathrm{Yu}, \mathrm{X}$; Luo, F; Zhang, Q ; Guo, L ; Hu, H; Yang, ZH; Grigoriev, SA; Cheng, H. A robust electrocatalytic activity and stability of Pd electrocatalyst derived from carbon coating, Int $\mathrm{J}$ Hydrogen Energy 44, 56 (2019) 29717-29723

https://doi.org/10.1016/j.ijhydene.2019.01.032

${ }^{4}$ Colmati, F; Magalhaes, MM; Sousa, R; Ciapina, EG; Gonzalez, ER. Direct Ethanol Fuel Cells: The influence of structural and electronic effects on Pt-Sn/C electrocatalysts, Int J Hydrogen Energy 4454 (2019) 28812-28820 https://doi.org/10.1016/j.ijhydene.2019.09.056

${ }^{5}$ Naulani-Garcia, M; Salinas-Torres, D; Mori, K; Kuwahara, Y; Yamashita, H. Enhanced formic acid dehydrogenation by the synergistic alloying effect of PdCo catalysts supported on graphitic carbon nitride, Int J Hydrogen Energy 4453 (2019)

https://doi.org/10.1016/j.ijhydene.2018.11.057

${ }^{6}$ Rajagopal S, Anwer MK, Spatola AF. Catalytic transfer hydrogenation and hydrogenolysis by formic acid and its salts. In: Basava C, Anantharamaiah GM, editors. Peptides.

Birkhäuser Boston

${ }^{7}$ Wright WRH, Palkovits R. Development of heterogeneous catalysts for the conversion of levulinic acid to $\gamma$-valerolactone. ChemSusChem 2012;5:1657-67

https://doi.org/10.1002/cssc.201200111

${ }^{8}$ Wang X, Meng Q, Gao L, Jin Z, Ge J, Liu C, Xing W. Recent progress in hydrogen production from formic acid decomposition. Int J Hydrogen Energy 2018;43:7055-71 https://doi.org/10.1016/j.ijhydene.2018.02.146

${ }^{9}$ Antolini E. Palladium in fuel cell catalysis. Energy Environ Sci 2009;2:915-931 https://doi.org/10.1039/b820837a

${ }^{10}$ Girisuta B, Janssen LPBM, Heeres HJ. A kinetic study on the conversion of glucose to levulinic acid. Chem Eng Res Des 2006;84:339-349 https://doi.org/10.1205/cherd05038

${ }^{11}$ Horvath IT, Mehdi H, Fabos V, Boda L, Mika LT. $\gamma$-Valerolactone - a sustainable liquid for energy and carbon-based chemicals. Green Chem 2008;10:238-42 https://doi.org/10.1039/B712863K

12 Wachała M, Grams J, Kwapinski W, Ruppert AM. Influence of $\mathrm{ZrO}_{2}$ on catalytic performance of $\mathrm{Ru}$ catalyst in hydrolytic hydrogenation of cellulose towards $\gamma$-valerolactone. Int J Hydrogen Energy 2016;41: 8688-95 https://doi.org/10.1016/j.ijhydene.2015.12.089

${ }^{13} \mathrm{Yu}$ Z, Lu X, Liu C, Han Y, Ji N. Synthesis of $\gamma$-valerolactone from different biomassderived feedstocks: Recent advances on reaction mechanisms and catalytic systems. Renewable and Sustainable Energy Reviews. 2019;112:140-157

${ }^{14}$ Dutta S, Yu I.K.M, Tsang D.C.W, Hau Ng Y, Sik Ok Y, Sherwood J, Clark J.H. Green synthesis of gamma-valerolactone (GVL) through hydrogenation of biomass-derived 
levulinic acid using non-noble metal catalysts: A critical review. Chem. Eng. J. 2019;371: 992-1006 https://doi.org/10.1016/j.cej.2019.04.199

${ }^{15}$ Fang H, Yang J, Wen M, Wu Q. Nanoalloy Materials for Chemical Catalysis Adv. Mater. $2018 ; 30: 1705698$ https://doi.org/10.1002/adma.201705698

${ }^{16}$ Singh AK, Xu Q. Synergistic catalysis over bimetallic alloy nanoparticles. ChemCatChem 2013;5:652-76 https://doi.org/10.1002/cctc.201200591

${ }^{17}$ Rodriguez JA. Physical and chemical properties of bimetallic surfaces. Surf Sci Rep 1996;24:223-87 https://doi.org/10.1016/0167-5729(96)00004-0

${ }^{18}$ Luo W, Sankar M, Beale A.M, He Q, Kiely Ch.J, Bruijnincx P.C.A, Weckhuysen B.M. High performing and stable supported nano-alloys for the catalytic hydrogenation of levulinic acid to $\gamma$-valerolactone. Nat. Commun. 2015;6: 6540 https://doi.org/10.1038/ncomms7540

${ }^{19}$ Yan L, Yao Q,Fu Y. Conversion of levulinic acid and alkyl levulinates into biofuels and high-value chemicals. Green Chem. 2017;19: 5527-47 https://doi.org/10.1039/c7gc02503c

${ }^{20}$ Ruppert A.M, Jędrzejczyk M, Sneka-Płatek O, Keller N, Dumon A.S, Michel C, Sautet P, Grams J. Ru catalysts for levulinic acid hydrogenation with formic acid as a hydrogen source. Green Chem. 2016;18: 2014-28 https://doi.org/10.1039/C5GC02200B

${ }^{21}$ Hengne A.M, Malawadkar A.V, Biradar N.S, Rode Ch.V. Surface synergism of an Ag$\mathrm{Ni} / \mathrm{ZrO}_{2}$ nanocomposite for the catalytic transfer hydrogenation of bio-derived platform molecules. RSC Adv. 2014;4: 9730-36 https://doi.org/10.1039/C3RA46495D

22 Upare P.P, Jeong M-G, Kyu Hwang Y, Han Kim D, Dok Kim Y, Won Hwang D, Lee U-H, Chang J-S. Nickel-promoted copper-silica nanocomposite catalysts for hydrogenation of levulinic acid to lactones using formic acid as a hydrogen feeder. Appl. Catal. A Gen. 2015;491: 127-35. https://doi.org/10.1016/j.apcata.2014.12.007

${ }^{23}$ Ruppert AM, Jędrzejczyk M, Potrzebowska N, Kaźmierczak K, Brzezińska M, Sneka-Płatek O, Sautet P, Keller N, Michel C, Grams J. Supported gold-nickel nano-alloy as a highly efficient catalyst in levulinic acid hydrogenation with formic acid as an internal hydrogen source. Catal Sci Technol 2018;8:4318-31 https://doi.org/10.1039/c8cy00462e

${ }^{24}$ Mandal K, Bhattacharjee D, Dasgupta S. Synthesis of nanoporous PdAg nanoalloy for hydrogen generation from formic acid at room temperature. Int J Hydrogen Energy 2015;40:4786-93 https://doi.org/10.1016/j.ijhydene.2015.02.060

${ }^{25}$ Choi B-S, Song J, Song M, Goo BS, Lee YW, Kim Y, Yang H, Han SW. Core-shell engineering of Pd-Ag bimetallic catalysts for efficient hydrogen production from formic acid decomposition. ACS Catal 2019;9,819-26 https://doi.org/10.1021/acscatal.8b044

${ }^{26}$ Hattori M, Einaga H, Daio T, Tsuji M. Efficient hydrogen production from formic acid using $\mathrm{TiO}_{2}$-supported AgPd@Pd nanocatalysts. J Mater Chem A 2015;3:4453-61 https://doi.org/10.1039/C4TA06988A

${ }^{27}$ Huang Y, Xu J, Ma X, Huang Y, Li Q, Qiu H. An effective low Pd-loading catalyst for hydrogen generation from formic acid. Int J Hydrogen Energy 2017;42:18375-82 https://doi.org/10.1016/j.ijhydene.2017.04.138 
${ }^{31}$ Zhou X, Huang Y, Xing W, Liu C, Liao J, Lu T. High-quality hydrogen from the eatalyzed decomposition of formic acid by $\mathrm{Pd}-\mathrm{Au} / \mathrm{C}$ and $\mathrm{Pd}-\mathrm{Ag} / \mathrm{C}$. Chem Comm 2008;30:3540-2 https://doi.org/10.1039/B803661F

${ }^{28}$ Liu J, Lan L, Li R, Liu X, Wu C. Agglomerated Ag-Pd catalyst with performance for hydrogen generation from formic acid at room temperature. Int J Hydrogen Energy 2016;41:951-8 https://doi.org/10.1016/j.ijhydene.2015.10.144

${ }^{29}$ Herron JA, Scaranto J, Ferrin P, Li S, Mavrikakis M. Trends in formic acid decomposition on model transition metal surfaces: A density functional theory study. ACS Catal 2014;4:4434-45 https://doi.org/10.1021/cs500737p

${ }^{30}$ Wang P, Steinmann SN, Fu G, Michel C, Sautet P. Key role of anionic doping for $\mathrm{H}_{2}$ production from formic acid on $\mathrm{Pd}(111)$. ACS Catal 2017;7:1955-9

https://doi.org/10.1021/acscatal.6b03544

${ }^{31}$ Wang D., Li T., Liu Y., Huang J., and You T. Large-Scale and Template-Free Growth of Free-Standing Single-Crystalline Dendritic Ag/Pd Alloy Nanostructure Arrays. Crystal Growth \& Design 2009, 9 (10), 4351-4355. DOI: 10.1021/cg900217t.

${ }^{32}$ Hao Fang Jinhu Yang Ming Wen Qingsheng Wu. Nanoalloy Materials for Chemical Catalysis Adv. Mater. 2018, 30, 1705698 https://doi.org/10.1002/adma.201705698

${ }^{33}$ Cho J, Lee S, Han J, Yoon SP, Nam SW, Choi SH, Lee K-Y, Ham HC. Importance of ligand effect in selective hydrogen formation via formic acid decomposition on the bimetallic Pd/Ag catalyst from first-principles. J Phys Chem C 2014;118:22553-60 https://doi.org/10.1021/jp5050817

${ }^{34}$ Zhang R, Yang M, Peng M, Ling L, Wang B. Understanding the role of Pd:Cu ratio, surface and electronic structures in $\mathrm{Pd}-\mathrm{Cu}$ alloy material applied in direct formic acid fuel cells. Appl Surf Sci 2019;465:730-9 https://doi.org/10.1016/j.apsusc.2018.09.196

${ }^{35}$ M. S. Doniach, S. Sunjic, Journal of Physics C: Solid State Physics, 1970, 3, 285. https://doi.org/doi:10.1088/0022-3719/3/2/010

${ }^{36}$ D. A. Shirley, Phys. Rev. B, 1972, 5, 4709-4714. doi:10.1103/PhysRevB.5.4709

${ }^{37}$ C.D. Wagner, L.E. Davis, M.V. Zeller, J.A. Taylor, R.M. Raymond, L.H. Gale, Surf. Interface Anal. 3 (1981) 211-225.

${ }^{38}$ Kresse G, Hafner J. Ab initio molecular dynamics for liquid metals. Phys Rev B 1993;47: 558-61 https://doi.org/10.1103/PhysRevB.47.558

${ }^{39}$ Perdew JP, Burke K, Ernzerhof M. Generalized gradient approximation made simple. Phys Rev Lett 1996;77:3865-8 https://doi.org/10.1103/PhysRevLett.77.3865

${ }^{40}$ Steinmann SN, Corminboeuf C. A generalized-gradient approximation exchange hole model for dispersion coefficients. J Chem Phys 2011;134:044117-1-5 https://doi.org/10.1063/1.3545985

${ }^{41}$ Steinmann SN, Corminboeuf C. Comprehensive benchmarking of a density-dependent dispersion correction. J Chem Theory Comput 2011;7:3567-77

https://doi.org/10.1021/ct200602x

42 Gautier S, Steinmann S N, Michel C, Fleurat-Lessard P, Sautet P. Molecular adsorption at Pt (111). How accurate are DFT functionals? Phys Chem Chem Phys 2015;17:28921-30 https://doi.org/10.1039/C5CP04534G 
${ }^{43}$ Blöchl PE. Projector augmented-wave method. Phys Rev B 1994;50:17953-79 https://doi.org/10.1103/PhysRevB.50.17953

${ }^{44}$ Kresse G, Joubert D. From ultrasoft pseudopotentials to the projector augmented-wave method. Phys Rev B 1999;59:1758-75 https://doi.org/10.1103/PhysRevB.59.1758

${ }^{45}$ Monkhorst HJ, Pack JD. Special points for Brillouin-zone integrations. Phys Rev B 1976;13:5188-92 https://doi.org/10.1103/PhysRevB.13.5188

${ }^{46}$ Kua J, Thrush KL. HCN, formamidic acid and formamide in aqueous solution: A freeenergy map. J Phys Chem 2016;120:8175-85 https://doi.org/10.1021/acs.jpcb.6b01690

${ }^{47}$ Wang P, Steinmann SN, Fu G, Michel C, Sautet P. Key role of anionic doping for $\mathrm{H}_{2}$ production from formic acid on $\mathrm{Pd}(111)$. ACS Catal 2017;7:1955-9

https://doi.org/10.1021/acscatal.6b03544

${ }^{48}$ Henkelman G, Uberuaga BP, Jonsson HJ. A climbing image nudged elastic band method for finding saddle points and minimum energy paths. Chem Phys 2000;113;9901-4 https://doi.org/10.1063/1.1329672

${ }^{49}$ Sheppard D, Terrell R, Henkelman G. Optimization methods for finding minimum energy paths. J Chem Phys 2008;128:134106-1-10 https://doi.org/10.1063/1.2841941

${ }^{50}$ Fleurat-Lessard P, http://perso.ens-lyon.fr/paul.fleurat-lessard/ReactionPath.html, 2017

${ }^{51}$ Henkelman G, Jonsson H. A dimer method for finding saddle points on high dimensional potential surfaces using only first derivatives. J Chem Phys 1999;111:7010-22 https://doi.org/10.1063/1.480097

${ }^{52}$ Kozuch S, Shaik S. How to conceptualize catalytic cycles? The energetic span model. Acc Chem Res 2011;44(2):101-10 https://doi.org/10.1021/ar1000956

${ }^{53}$ Kozuch S, Martin JM. The rate-determining step is dead. Long live the rate-determining state! ChemPhysChem 2011;12;1413-8 https://doi.org/10.1002/cphc.201100137

${ }^{54}$ Ruppert AM, Grams J, Matras-Michalska J, Chełmicka M, Przybysz P. ToF- SIMS study of the surface of catalysts used in biomass valorization. Surf. Interface Anal 2014;46:726-30 https://doi.org/10.1002/sia.5370

${ }^{55}$ Praserthdam P, Ngamsom B, Bogdanchikova N, Phatanasri S, Pramotthana M. Effect of the pretreatment with oxygen and/or oxygen-containing compounds on the catalytic performance of Pd-Ag/ $/ \mathrm{Al}_{2} \mathrm{O}_{3}$ for acetylene hydrogenation. App Catal A-Gen 2002;230:41-51 https://doi.org/10.1016/S0926-860X(01)00993-0

${ }^{56}$ Heinrichs B, Noville F, Schoebrechts J-Ps, Pirard J-P. Palladium-silver sol-gel catalysts for elective hydrodechlorination of 1,2-dichloroethane into ethylene. J Catal 2000;192:108$18 \mathrm{https}$ ///doi.org/10.1006/jcat.2000.2816

${ }^{57}$ L'vov BV, Ugolkov VL. Kinetics and mechanism of free-surface decomposition of solidand melted $\mathrm{AgNO}_{3}$ and $\mathrm{Cd}\left(\mathrm{NO}_{3}\right)_{2}$ analyzed thermogravimetrically by the third-law method. Thermochim Acta 2004;424:7-13 https://doi.org/10.1016/j.tca.2004.05.005

${ }^{58}$ Ebin B, Yazici E, Sebahattin Gurmen S. Production of nanocrystalline silver particles by hydrogen reduction of silver nitrate aerosol droplets. Trans Nonferrous Met Soc China 2013;23: 841-48 https://doi.org/ 10.1016/S1003-6326(13)62537-6 
${ }^{59}$ Zhang Q, Li J, Liu X, Zhu Q. Synergetic effect of $\mathrm{Pd}$ and $\mathrm{Ag}$ dispersed on $\mathrm{Al}_{2} \mathrm{O}_{3}$ in the selective hydrogenation of acetylene. App Catal A-Gen 2000;197:221-28 https://doi.org/10.1016/S0926-860X(99)00463-9

${ }^{60}$ Gauthard F, Epron F, Barbier J. Palladium and platinum-based catalysts in the catalytic reduction of nitrate in water: effect of copper, silver, or gold addition. J Catal 2003;220:18291 https://doi.org/10.1016/S0021-9517(03)00252-5

${ }^{61} \mathrm{Ahn}$ IY, Lee JH, Kim SK, Moon SH. Three-stage deactivation of $\mathrm{Pd} / \mathrm{SiO}_{2}$ and $\mathrm{Pd}-\mathrm{Ag} / \mathrm{SiO}_{2}$ catalysts during the selective hydrogenation of acetylene. App Catal A-Gen 2009;360:38-42 https://doi.org/10.1016/j.apcata.2009.02.044

${ }^{62}$ Lamb RN, Ngamsom B, Trimm DL, Gong B, Silveston PL, Praserthdam P. Surface characterisation of $\mathrm{Pd}-\mathrm{Ag} / \mathrm{Al}_{2} \mathrm{O}_{3}$ catalysts for acetylene hydrogenation using an improved XPS procedure. App Catal A-Gen 2004;268:43-50

https://doi.org/10.1016/j.apcata.2004.03.041

${ }^{63}$ Gomez-Sainero LM, Seoane XL, Fierro JLG, Arcoya A. Liquid-phase hydrodechlorination of $\mathrm{CCl}_{4}$ to $\mathrm{CHCl}_{3}$ on $\mathrm{Pd}$ /carbon catalysts: Nature and role of $\mathrm{Pd}$ Active species. J Catal 2002;209:279-88 https://doi.org/ 10.1006/jcat.2002.3655

${ }^{64}$ Schmal M, Aranda DAG, Noronha FB, Guimaraes AL, Monteiro RS. Oxidation and reduction effects of propane-oxygen on Pd-chlorine/alumina catalysts. Catal Lett 2000;64: 163-169. https://doi.org/10.1023/A:1019034903453

${ }^{65}$ Mazzieri V, Coloma-Pascual F, Arcoya A, L'Argentiere PC, Figoli NS. XPS, FTIR and TPR characterization of $\mathrm{Ru} / \mathrm{Al}_{2} \mathrm{O}_{3}$ catalysts, Appl. Surf. Sci. 2003;210:222-230. https://doi.org/10.1016/S0169-4332(03)00146-6

${ }^{66}$ R. N Lamb, B. Ngamsom, D.L Trimm, B. Gong, P.L. Silveston, P. Praserthdam, Surface characterisation of $\mathrm{Pd}-\mathrm{Ag} / \mathrm{Al}_{2} \mathrm{O}_{3}$ catalysts for acetylene hydrogenation using an improved XPS procedure, Applied Catalysis A: General 268 (2004) 43-50, https://doi.org/10.1016/j.apcata.2004.03.041

${ }^{67}$ A.M Venezia, L.F Liotta, G Deganello, Z Schay, L Guczi, Catalytic CO oxidation over pumice supported Pd-Ag catalysts, J. Catal., 182 (1999) 449, https://doi.org/10.1016/S0926860X(00)00870-X

${ }^{68}$ L.F Liotta, A.M Venezia, G Deganello, A Longo, A Martorana, Z Schay, L Guczi, Liquid phase selective oxidation of benzyl alcohol over $\mathrm{Pd}-\mathrm{Ag}$ catalysts supported on pumice, Catal. Today, 66 (2001) 271, https://doi.org/10.1016/S0920-5861(00)00650-7

${ }^{69}$ Grasemann M, Laurenczy G. Formic acid as a hydrogen source - recent developments and future trends. Energy Environ Sci 2012;5:8171-81 https://doi.org/10.1039/C2EE21928J

${ }^{70}$ Stamatakis M, Chen Y, Vlachos DG. First-principles-based kinetic monte carlo simulation of the structure sensitivity of the water gas shift reaction on platinum surfaces. J Phys Chem C 2011;115:24750-62 https://doi.org/10.1021/jp2071869 